\title{
Tecido urbano e mercado imobiliário em São Paulo: metodologia de estudo com base na Décima Urbana de 1809
}

Beatriz Piccolotto Siqueira Bueno

Faculdade de Arquitetura e Urbanismo da USP

RESUM 0: Este artigo apresenta uma metodologia inédita de espacialização da Décima Urbana, primeiro imposto predial estabelecido para as cidades brasileiras. Focaliza o caso de São Paulo, em 1809. Os dados recolhidos na documentação textual foram processados em banco de dados e cartografados na primeira planta cadastral da cidade, elaborada pelo engenheiro C arlos Bresser, entre 1844-1847, e confrontados com a documenta ção iconográfica dos viajantes e de Militão Augusto de Azevedo, de modo a precisar as informações obtidas. A Décima Urbana de 1809 contém informações sobre a localização dos imóveis, seus proprietários, inquilinos, tipologias (casas térreas, sobrados, lojas), finalidades (uso próprio, aluguel), usos (residencial, comercial, misto) e valor, que hoje nos permitem reconstituir hipoteticamente o velho tecido urbano da cidade de São Paulo e aspectos da dinâmica do seu mercado imobiliário em fins do período colonial.

Pa LAVRAS-ChaVE: São Paulo. Décima Urbana. Tecido U rbano. M ercado imobiliário rentista. Período Colonial.

ABSTRACT: This article presents a new spatialisation methodology for the Décima Urbana, the first property tax established in Brazilian cities. The case of São Paulo in 1809 is studied. The data gathered from textual documentation was processed in a database and cartographed on the first official city plan, elaborated by engineer $C$ arlos Bresser betw een 1844-1847, and then confronted with the iconographic documentation produced by visiting travellers and by photog ra pher M ilitão Augusto de Azevedo, so as to cross-reference the information obtained. The Décima Urbana of 1809 contains data about the siting of buildings, their proprietors, tenants, typology (single and tw 0 -sto rey houses, shops), finalities (ow n use, rent), uses (residential, commercial, mixed) and value. This allows for the present day hypothetical reconstruction of old São Paulo's urban mesh and of aspects of the real estate market dynamics at the end of the colonial period.

KEYW 0 RDS: São Paulo. Décima urbana. Urban mesh. Property Rent M arket. Colonial Period. 
1. Esta pesquisa é parte de um Projeto Temático financiado pela Fapesp intitulado Urbanização dispersa emudanças no tecido urbano.Estudo de caso: Estado de São Paulo, que está sendo desenvolvido no Laboratório de Estudos sobre Urbani zação,Arquitetura e Preservação (LAP), da Faculdade de Arquitetura e Urbanismo da USP, sob a coordenação geral do Prof. Dr. Nestor Goulart Reis Filho. Dentro dos objetivos do projeto temático, sob nossa coordenação, subtema específico contempla o velho tecido urbano da cidade de São Paulo em paralelo ao estudo da dinâmica do seu mercado imobiliário. Se propõe a analisar a questão numa perspectiva histórica, de longa duração, enfocando de 1809 a 1950. Por não se tratar de um período homogêneo, dividimos a pesquisa em três módulos: 1809 a 1870; 1870 a 1930; 1930 a 1950. Neste artigo, apresentaremos algumas conclusões referentes ao período colonial, com base em documentação pouco utilizada pelos historiado res, geógrafos, arquitetos, urbanistas e economistas, de extrema relevância pa ra pesquisas dessa natureza.

2. Foi critério da autora manter a grafia de nomes dos proprietários como são citados na Décima Urbana de 1809
Reconstituir hipoteticamente a velha tessitura da cidade de São Paulo e os agentes sociais envolvidos na sua produção, em fins do período colonial, foi um dos desa fios a ssumidos neste artigo, parte de uma pesquisa em anda mento ${ }^{1}$. Ao espacializarmos uma documentação inédita, a Décima Urbana de 1809 , pudemos constatar aspectos surpreendentes da cidade de São Paulo, ja ma is enfocados pela historiografia. Verificamos que boa parte do tecido urbano era produto da iniciativa privada e $50 \%$ das casas destinadas à renda de aluguel. Constatamos a existência de um mercado imobiliário "rentista" na São Paulo colonial e considerável concentração de imóveis nas mãos das ordens religiosas, em especial dos beneditinos, detentores de 61 prédios. No entanto, se individualmente foram as ordens religiosas os principais ag entes detentores do patrimônio imobiliário urbano paulistano, no conjunto, $81 \%$ dos prédios eram patrimônio laico, envolvendo nomes conhecidos como os dos Coronéis Luiz Antônio de Souza e Jozé Arouche de Toledo, bem como outros menos famosos de comerciantes e negociantes. ${ }^{2}$

A elite tinha muitas vezes dupla morada, em geral gozando de chácaras nos arredores da cidade e de amplos sobrados nas ruas centrais. $\mathrm{N} 0$ entanto, em 1809 , os célebres sobrados dos $Q$ uatro $C$ antos pertencentes a os Prados e jordãos ainda não haviam sido construídos. Também o sobrado de ângulo, na esquina das ruas do 0 uvidor e São Bento, pertencente ao futuro Brigadeiro Luiz Antônio não estava lá; correspondia ainda a uma simples loja e um lanço - a C asa Souza - onde o proprietário praticava um dos seus importantes negócios.

N ão foi tarefa fácil espacializar a Décima, sendo fundamental a eleição de um mapa-base contemporâneo à documentação manuscrita - a planta cadastral de C arlos Bresser (1844-1847) -, sendo igualmente árduo simular o percurso do fiscal inventariante - responsável pela atribuição do imposto -, por vezes pouco objetivo. A metodologia de pesquisa consistiu portanto de quatro procedimentos associados: 1) compilação dos dados da documentação manuscrita localizada no Arquivo do Estado de São Paulo; 2) aplicação das informações obtidas na Décima, lote a lote, no mapa-base escolhido; 3 ) confrontação dos dados com a iconografia dos viajantes contemporâneos ao período - Ender (1817), Pallière (1821), Edmund Pink (1823), Burchell (1827) - e com as fotos de M ilitão Augusto de Azevedo; 4 ) verificação de alguns imóveis sabidamente pertencentes a certas fa mílias, via fontes secundárias. $N$ esse sentido, a tese de doutorado de Paulo G arcez M arins foi de extrema valia, além das fichas do Fundo Aguirra do M useu Paulista, que ainda merecem estudo mais detido.

A documentação iconográfica de viajantes para a cidade de São Paulo é escassa e parcial, focalizando especialmente os Largos da Sé, M isericórdia e do Colégio. Ao contrário, as fo tos de M ilitão Augusto de Azevedo são muito mais fartas e espacialmente abrangentes. Embora correspondam à segunda metade do século XIX, tais fotog rafias nos permitem entrever as velhas 
casas térreas e sobrados de beirais largos, vergas retas ou de arco abatido, com rótulas e muxarabis do período colonial, em meio às edificações alteadas, maquiadas de platibandas, ferragens e vidraças. A interpretação da documentação iconográfica precisa, portanto, a volumetria sugerida pela Décima de 1809.

Possivelmente ocorreram imprecisões, mas a lg uns aspectos de conjunto podem ser inferidos desde já. Trata-se de uma cidade concentrada na colina entre os rios Anhangabaú e Tamanduateí, predominantemente térrea (86\%) e residencial ( $86 \%$ ), com sobrados localizados em determinadas ruas de uso misto, correspondendo às áreas mais valorizadas da cidade.

Ao descortinarmos os proprietários e inquilinos das casas e lojas, surgiu o perfil da população urbana e o cenário ganhou vida, permitindo elucidar a specto s obscuros da histo riog rafia, inferir outros e vislumbrar futuras linhas de pesquisa ainda inexploradas sobre a velha São Paulo.

\section{A histo riografia}

Divulgada nos estudos de Ra quel G lezer, mas a inda inexplorada desse ponto de vista, a Décima Urbana foi o primeiro imposto predial, estabelecido para a Corte e principais vilas, cidades e lugares notáveis da faixa litorânea, pago à Fazenda Real, correspondendo a $10 \%$ do rendimento líquido de todos os bens de raiz, incidindo sobre proprietários e inquilinos, com exceção daqueles pertencentes às Santas Casas de M isericórdia. Ampliado em sua área de abrangência, por Alvará emitido ainda em 3/6/1809, o tributo foi estendido a todas as povoa ções, para além da faixa costeira, mantendo as mesmas isenções do texto anterior e reforçando a exigência de pronto pagamento.

Para fins de tributação, resulto u no a rrola mento, em livro específico, de todos os prédios circunscritos no perímetro urbano, então definido para tanto, bem como na primeira numeração dos edifícios da cidade. $N$ esse sentido, contém informa ções preciosas sobre a loca lização dos imóveis, seus prop rietários, inquilinos (em caso de imóvel de aluguel), tipologias, finalidades, usos e valor (do prédio e do aluguel), que hoje nos permitem reconstituir o velho tecido urbano do a tual centro histórico da cidade de São Paulo, em 1809, e entender aspectos do seu mercado imobiliário.

Convém salientar que a Décima Urbana teve longa vida, apesar dos percalços iniciais para sua cobrança. Sua escala de abrangência e alíquota foram alteradas em 1867 :

[...] cobrança de $12 \%$ na décima adicional dos prédios das corporações de mão morta, os prédios dos bancos, companhias e sociedades anônimas, e associações pias, beneficentes ou religiosas, incluindo no valor locativo o do terreno anexo (G LEZER, 1992, p.102-103). 
A Décima Urbana tornou-se sinônimo de área urbana. Por ser sinônimo de área urbana, presta-se de maneira exemplar à reconstituição da sua tessitura.

Embora muito tenha sido escrito sobre a cidade de São Paulo, escassa é a literatura sobre essas questões. Do ponto de vista do traçado planimétrico e volumétrico, os estudos recentes de N estor G oula rt Reis Filho (2004) e Benedito Lima de Toledo (2004) muito a crescentaram ao já conhecido.

Do ponto de vista dos agentes sociais, produção e vivência do espaço urbano, no que diz respeito à casa comum, à exceção do capítulo "Sociabilidades paulistanas", ainda inédito, da tese de Paulo Garcez Marins (1999), com base nos inventários post-mortem e na iconografia, raros foram os estudos de conjunto a descortinar essas questões. Pioneiro na localização e estudo do perfil social dos moradores das famosas casas térreas e sobrados de rótulas estampados nas fotos de Militão Augusto de Azevedo, o autor desenvolveu minuciosa metodologia de pesquisa, envolvendo o confronto de fontes documenta is diversas - inventários, cartografia, iconografia, antigas numerações das ruas da cidade de São Paulo e a Décima Urbana de 1872.

$\mathrm{N}$ a mesma linha, ma is recentemente, o doutorado de $\mathrm{M}$ a ria Luiza Ferreira de 0 liveira $(2003)$ contemplou aspectos das relações sociais, do cotidiano dos setores médios e do mercado imobiliário "rentista" na cidade de São Paulo, entre 1870-1900, ta mbém com base nos inventários de família.

Em relação a pesquisas sobre a história do mercado imobiliário na cidade, acreditava-se que o mesmo fosse inexistente no período colonial. À exceção dos trabalhos pioneiros de Fania Fridman (1999) e N ireu Cavalcanti (2004), circunscritos a o caso carioca, nada foi escrito sobre patrimônio e merca do imobiliário urbano em tempos tão recuados.

O s estudos de João Luís Fragoso (1998) apontaram para a questão a o demonstrar que a maioria das propriedades imobiliárias do centro do Rio estavam concentradas nas mãos de ricos comerciantes. $\mathrm{N} 0$ entanto, apenas Fania Fridman - com base na documentação oficial dos A rquivos da Cúria Metropolitana do Rio de Janeiro - e N ireu Cavalcanti - com base nos Livros da Décima Urbana da Corte de 1809 a 1812 - caracterizaram a sua existência, natureza e dinâmica específica.

0 utros estudos foram desenvolvidos sobre a matéria, enfocando no entanto períodos mais recentes. Convém destacar as dissertações de mestra do do historiador Reinéro Lérias (1988) e da geógrafa M ônica Silveira Brito (2000) - ambas com foco em São Paulo na Primeira República - e do arquiteto W alter Pires (2003) - com foco específico nas estruturas fundiárias dos a tua is bairros do Cambuci, Jardim da G lória e Chácara Klabin, entre 1876 e 1904.

Para as questões relacionadas às transforma ções urbanísticas na á rea central da cidade de São Paulo, correspondente à antiga Freguesia da Sé, na Primeira República (1889-1930), é fundamental a tese de doutorado de Heloisa Barbuy (2001) que enfoca as mudanças nos hábitos de consumo do paulistano em paralelo às mudanças nos usos e tipologias dos edifícios, bem como os 
agentes sociais envolvidos. Igualmente importantes são as teses de Cândido M alta Campos N eto (2002) e José G eraldo Simões Jr (1985), focalizando as intervenções urba nísticas induzidas ou pa trocinadas pelas administra ções de Antônio Prado, Raimundo Duprate dema is prefeitos na zona do triângulo histórico (formado pelas ruas 15 de N ovembro, São Bento e Direita), na Rua Líbero Badaró e no Vale do Anhangabaú.

A metodologia de pesquisa

Para obtermos alguns produtos da Décima Urbana de 1809 , elaboramos um banco de dados específico para a pesquisa, contendo os seguintes campos:

- Cidade.

- A no do inventário.

- Freguesia .

- Logradouro, número.

- N ome do proprietário (indicação se leigo ou religioso, particular, institucional, ordem religiosa, irmandade, padre secular).

- Nome dos inquilinos.

- Tipologia do imóvel (sobrado, casa térrea, assobradado).

- Subtipologia do imóvel (casa térrea de um a qua tro lanços, loja, sobrado de um a três lanços, com ou sem loja, de um, dois ou três andares).

- Uso (residencial, comercial, misto).

- Finalidade (aluguel, uso próprio, cedido, em obras, outros).

- Valor do imóvel.

- Valor do aluguel/ mês.

- Valor da Décima Urbana.

Alimentamos o banco de dados com todas as informações coletadas no Livro de 1809 e obtivemos alguns relatórios parciais, que nos permitiram tecer considerações sobre os principais proprietários de imóveis urba nos, localização dos prédios, montante investido em patrimônio imobiliário urbano e natureza específica do mercado imobiliário vigente em fins do período colonial, a saber: a) rela tório geral contendo a quantificação dos imóveis catalogados por tipologia, 
3. Fundo pertencente ao Serviço de Documentação Textual e Iconográfica do Museu Paulista-USP, desde 1962, contém uma preciosa coleção de fichas, mapas, cadastros, livros e fotografias, organizadas por João Baptista de Campos Aguirra, em mais de 20 anos de pesquisa nos cartórios da cidade, envolvendo informações sobre as transações imobiliárias realizadas do período colonial à Primeira República, rua a rua

4. Em parceria com Paulo Garcez Marins. tipo de proprietário, usos e finalidades; b) lista da quantidade de imóveis por proprietário e valor total do montante imobilizado em patrimônio imobiliário urbano por eles; c) lista de proprietários contendo os endereços de todos os seus imóveis; d) lista decrescente do valor dos imóveis e respectivos endereços.

Para a reconstituição de aspectos concretos do tecido urbano de São Paulo, em 1809 , cartografamos todas as informações a rroladas no inventário da Décima na primeira planta cadastral da cidade - M appa da Cidade de São Paulo offerecido a sua M agestade... - elaborada pelo engenheiro $C$ arlos Bresser, entre 1844-1847, eleita mapa-base para essa etapa da pesquisa. As informações nele cartografadas, resultaram em quatro pranchas inéditas: Prancha I - tipologias predominantes (casas térreas ou sobrados); Prancha II - finalidade dos imóveis (uso próprio ou aluguel); Prancha III - usos (residencial, comercial ou misto); Prancha IV - principais agentes detentores de patrimônio imobiliário urbano (leigos e religiosos).

Convém ressaltar que as informações disponibilizadas no inventário de 1809 foram confrontadas com outros três mapas de São Paulo datados de 1810, a saber: Planta da Cidade de S. Paulo [...] levantada em 1810 pelo Engenheiro Rufino Felizardo e Costa (REIS FILHO, 2004: p. 86); Planta da Imperial Cidade de São Paulo, levantada em 1810 pelo Engenheiro Rufino Felizardo e Costa e copiada em 1841 com todas as alterações (REIS FILHO, 2004 , p. 119) e Carta da capital de São Paulo que o Exmo. Snr. Barão de Caxias mandou executar pelo Engenheiro da Columna José Jacques da Costa 0 urique, Fortificador da capital, 1842 (REIS FILHO , 2004, p. 121).

$\mathrm{N}$ a preparação dos mapas, em Adobe Photoshop, contamos com a colaboração de $M$ arcos Fernandes $C$ alixto Rios, bolsista de iniciação científica do Projeto Temático, que sob nossa orientação está desenvolvendo pesquisa específica sobre a Rua 15 de Novembro, de 1809 a 1954, aprofundando questões referentes às transações imobiliárias e mudanças a rquitetônicas e de uso na área central da cidade.

Em paralelo, também com o auxílio gráfico do aluno Marcos Rios, preparamos as pranchas focalizando aspectos de algumas ruas e largos da cidade de São Paulo no período, com base na Décima de 1809 e na iconografia disponível, nomeando os proprietários das casas e dando vida ao cenário. A presentaremos aqui o caso do Largo da Sé, confrontando imagens de Thomas Ender (1817), Edmund Pink (1821-1833), W illiam John Burchell (1827) e M ilitão Augusto de Azevedo com os dados fornecidos pela Décima. Para tanto, foi essencial 0 recurso ao Fundo Aguirra $^{3}$ que possibilitou a checagem da localização dos imóveis.

0 exame do livro da Décima Urbana de 1809 e o mapeamento das informações - em planimetria e volumetria - nos permitiu reconstituir aspectos do espaço intra-urbano da cidade de São Paulo, bem como esboçar um quadro do seu patrimônio e mercado imobiliário rentista, predominante em todas as cidades colonia is e imperia is brasileiras, ao menos até os anos 70 do século XIX, dando subsídios para comparações futuras com os períodos subseqüentes e casos a fins.

Essa metodologia piloto será a plicada aos demais registros da Décima Urbana disponíveis sobre São Paulo, 1829 e $1872^{4}$, e sobre Santos (1814, 
1835-1836, $1836-1837$ e 1837-1838), viabilizando o aprofundamento de questões aqui esboçadas.

\section{Algumas constata ções}

Q uando comparamos os dados estatísticos relativos a o velho tecido urbano da cidade de São Paulo e seu mercado imobiliário no início do século XIX com os dados referentes à megalópole do século XXI, surpreende-nos a dinâmica do seu processo de urbanização. Hoje falamos em "dispersão" para caracterizar as novas configurações atuais. No entanto, a mancha urbanizada, composta pela Região Metropolitana de São Paulo e seus 39 municípios, correspondia aos limites (o Termo) do município nas suas origens. 0 que hoje chamamos de $\mathrm{C}$ entro Histórico correspondeu, do século XVI ao último quartel do XIX, à a rea efetivamente urbanizada da cidade. A antiga Freguesia da Sé oscilava em torno de 7.000 habitantes em princípios do 0 itocentos e 0 município em torno de 24.000 habitantes. Hoje, a área municipal abriga um total de 11 milhões de pessoas, e a Região M etropolitana gira em torno dos 17 milhões.

N ossa memória não alcança aspectos significativos do espaço intraurbano nas suas origens. Recuamos no tempo, portanto, para caracterizá-to.

São bastante conhecidas as descrições dos viajantes, como as de Saint-Hilaire, que apontam aspectos de São Paulo em princípios do século XIX (1819 e 1822):

Eu não saberia dizer qual é o número de casas da cidade de São Paulo, mas Spix e Martius nos informam que, em 1815, quando o distrito de que a cidade era sede ainda compreendia 12 paróquias, havia ali um total de 4142 famílias; segundo Eschwege, haveria em 1820 nesse distrito, já reduzido a 11 paróquias, 4017 famílias, finalmente, de acordo com Daniel Pedro M üller, as 9 paróquias e a sucursal de que se compunha o distrito contariam, em 1839, com um total de 4168 . Eschwege, supondo que as cifras relativas a todo o distrito se referem unicamente à cidade de São Paulo, a firma existirem nessa cidade 6 pessoas por casa. [...]

Funcionários de todas as categorias, artesãos de variadas profissões, numerosos negociantes, proprietários de casas urbanas e de terras - os quais, a o contrário de $M$ inas $G$ erais, não moram nas suas fazendas - compõem a população da cidade de São Paulo [...]

A cidade fica situada [...] numa elevação [...]. Seu contorno é bastante irregular e de forma ligeiramente alongada, situando-se ela no delta formado pelos córregos Anhangabaú e Tamanduatéí, os qua is [...] vão desaguar no Tietê" [...]

As casas, feitas de taipa e bastante sólidas, são todas caiadas e cobertas de telhas. $\mathrm{N}$ enhuma delas sugere opulência, mas vê-se um grande número de sobrados, que chamam atenção por seu aspecto vistoso e limpo. 0 s telhados não se projetam muito para fora, a penas o suficiente para darem sombra e protegerem as paredes da chuva, e as janelas não são tão juntas umas das outras, como se vê comumente no Rio de Janeiro. As dos sobrados são quase todas envidraçadas, com postigos pintados de verde e com sacadas. As casas de um só pavimento têm gelosias que se abrem de baixo para cima e são feitas de paus cruzados em diagonal (SAIN T-HILAIRE, 1976, p.126-128). 
Se os dados sobre a população de São Paulo são pouco precisos na fala dos viajantes, com base no Recenseamento de 1776 e nas informações fornecidas por Afonso de Freitas, em 1822, sabemos que a cidade passou de 2.026 habitantes e 574 prédios para 6.920 habitantes apenas no distrito da Sé e 24.000 no município (REIS FILHO , 2004, p. 70/80). 0 s dados arrolados na Décima Urbana de 1809 nos permitem precisar o quadro esboçado acima, recorrentemente invocado pela historiografia.

Podemos a firmar que o perímetro urbano da capital paulista se constrangeu de 1554 a c.1870 na estreita colina formada pelo curso dos rios Anhangabaú e Tamaduateí, com pouquíssimas ramificações na várzea, compondo-se de, segundo a Décima de 1809, um total de 34 ruas (Boa Vista, S. Bento, Jogo da Bola, da Bua (sic), do Comércio, Ca deia, Carmo, Ca choeira, C emitério, Direita, Esperança, S. Ifigênia, da Freira, das Flores, São Francisco ao Jogo da Bola, S. G onçalo, G uacû, do Hospital, de S. José, S. João, Lorena, Luz, 0 uvidor, Príncipe, Pombal, Piques, Q uartéis, Rosário a Boa Vista, Rego, Sé, Sé para S. Teresa, Tabatinguera, S. Teresa, Tanque), 13 travessas (do Bexiga, da Boa Vista, Casinhas, Comércio, Cemitério, do Colégio, S. Ifigênia, Fundição, da Lapa, do Príncipe, do Pombal, dos Q uartéis e de S. Teresa), um beco (Beco do Barbas) e quatro largos (Largo da Sé, Largo do Colégio, Largo de São G onçalo e Largo do Bexiga).

$\mathrm{N}$ esse perímetro urbano foram inventariados 1.281 imóveis para fins de tributação. Desses, $81,64 \%$ esta vam concentrados nas mãos de leigos e $18,27 \%$ nas mãos das ordens religiosas, irmandades e padres seculares.

São Paulo era uma cidade predominantemente térrea. Dos 1.211 imóveis cadastrados no item tipologia, apenas 161 eram sobrados (159 de um andar; um de dois andares e um de três andares), totalizando 13,29\% do conjunto do casario. As 1.047 edificações restantes eram casas térreas, correspondendo a $86,45 \%$ do tecido urbano (Figura 1 ).

Entre as casas térreas havia subtipologias, tais como: térreas simplesmente; térrea de uma loja; térrea de um lanço; térrea de dois lanços; térrea de três lanços; térrea de um lanço e uma loja; térrea de dois lanços e uma loja; térrea de uma loja e um corredor; térrea de um lanço e um corredor; térrea de um lanço e um "sotio"; térrea de dois lanços e um mirante. Entre os sobrados ta mbém, a saber: sobrado de um andar; sobrado de um lanço e um andar; sobrado de três lanços e um andar; sobrado de uma loja e um andar; sobrado de duas lojas e um andar; sobrado de três lojas e um andar; sobrado de quatro lojas e um andar; sobrado de cinco lojas e um andar; sobrado de seis lojas e um andar; sobrado de uma loja, um lanço e um andar; sobrado de um lanço, três lojas e um andar; sobrado de uma loja, dois corredores e um andar; sobrado de uma loja de primeiro e segundo andares; sobrado de três andares. N o conjunto foram identificadas duas casas assobradadas, que supomos tratar-se de sobrado de um lado e térrea do outro, decorrente do desnível do terreno.

Cabe explicar que segundo Antenor $\mathrm{N}$ ascentes, no seu Dicionário da língua portuguesa, a expressão "lanço" significava "extensão do pano de um muro, de uma parede, de uma fachada". Com base na iconografia, interpretamos a expressão "casa de um lanço" como uma moradia, térrea ou sobrado, de um único 


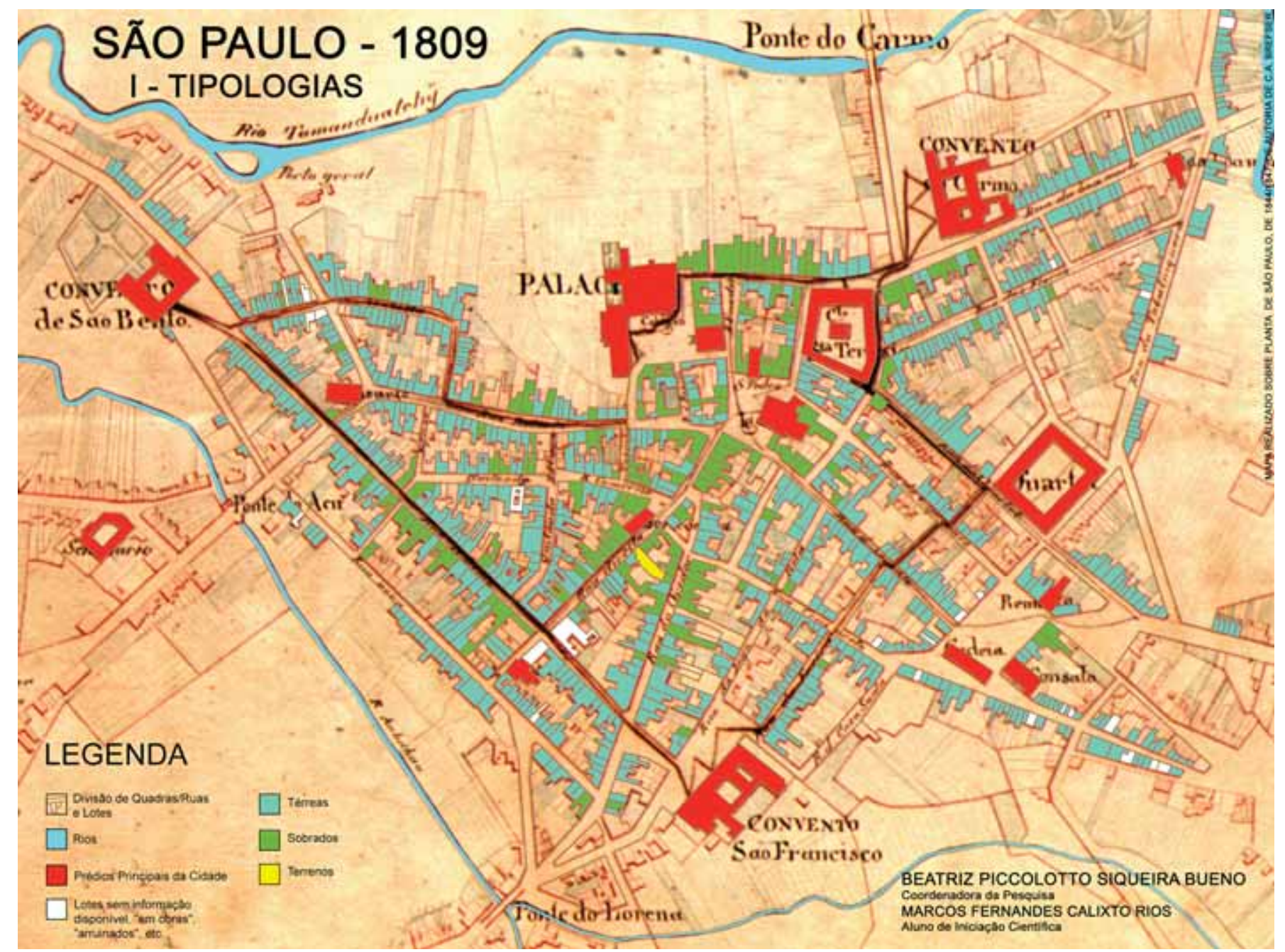

Figura 1 - Prancha I - Tipologias. Autora: Beatriz P. Siqueira Bueno. Mapa-base: "Mappa da Cidade de São Paulo offerecido a Sua Magestade, o Imperador pelo Presidente da Província Manoel da Fonseca lima e Silva (1844-1847)", do Engenheiro Carlos Bresser, datável de 1844-1847. Seção de Cartografia da Fundação Biblioteca N acional, Rio de Janeiro. 
5. Em caso de imóvel de uso misto ou exclusivamente comercial, com lojas na frente, em lugar das janelas observamos a presença de duas a três portas.

6. A "Junta da Décima da Cidade de São Paulo",em 1809, era composta pelo Escrivão da Executoria Antonio Xavier Ferreira; pelo Fiscal e Bacharel Manuel Joaquim de Ornellas; pelo Louvado Nobre o Tenente Coronel Francisco Alvares Ferreira do Amaral; pelo Louvado do Povo Louren ço da Silva Barros; pelos Carpinteiros José Ferreira e José Joaquim de Carvalho e pelo Pedreiro Manuel Roiz. Em 15/11/ 1809, o Louvado do Povo foi substituído por Thomé Manuel de Jezus Varella. Em 13/12/1809, 0 Fiscal e Bacharel Manuel Joaquim de Ornellas foi nomeado Superintendente da Décima, em lu gar do Desembargador Miguel Antonio Azevedo daVeiga - Ouvidor Geral Corregedor e Juiz Executor da Real Fazenda. Desde então, o posto de Fiscal da Décima foi encabeçado pelo Bacharel Miguel Carlos Aires de Carvalho, provável pro prietário da famosa chácara de mesmo nome, nas imediações da cidade. 0 lançamento do imposto incidiu sobre todos os prédios urbanos, e o inventário teve início na Rua Direita (Freguesia da Sé), em 10/11/1809, e conclusão na Rua do Tan que (Tanque do Zuniga, Freguesia de S. Ifigênia), em 30/12/1809. A soma do imposto recolhido em 1809, totalizou 1:302 $\$ 241$ rs (um conto, tre zentos e dois mil, duzentos e quarenta e um réis). Segundo Maria LucíliaViveiros de Araújo, 1\% dos cômodo frontal, com janela-porta-janela, uma porta e duas janelas ou, simplesmente, porta e janela ${ }^{5}$. Já uma casa de do is lanços seria composta de dois cômodos fronta is e assim sucessivamente, cada lanço resultaria no acréscimo de um cômodo ou extensão de fachada correspondente. 0 lanço seria portanto o módulo que orientava a a tribuição de valor aos imóveis, com base na medição das testadas. Sendo a São Paulo colonial uma cidade predominantemente de taipa de pilão, talvez 0 lanço equivalesse a dois taipais, totalizando $4,40 \mathrm{~m}$, uma vez que 0 taipal media uma braça (i.e. 2,20 m). 0 critério de avaliação dos imóveis urbanos envolvia também outras variáveis, tais como o número de pavimentos. $\mathrm{N}$ ão por acaso, a medição dos imóveis para fins de taxação era a tribuição de dois mestres carpinteiros e um mestre-pedreiro, funcionários da Junta da Décima ${ }^{6}$.

\begin{tabular}{lrr}
\hline & RELATÓ RIO G ERAL \\
\hline & QUAN TIDADE & \\
\hline Freguesias & & \\
Sé e Santa Ifigênia & 1.281 & $100 \%$ \\
\hline Tipos de proprietários & & \\
Leigos & 1.041 & $81,64 \%$ \\
Religiosos & 233 & $18,27 \%$ \\
Total & 1.275 & \\
\hline Tipologia & & \\
Assobradada & 2 & $0,16 \%$ \\
Sobrado & 161 & $13,29 \%$ \\
Térrea & 1.047 & $86,45 \%$ \\
Terreno & 1 & $8,25 \%$ \\
Total & 1.211 & \\
\hline Finalidade & & \\
Auguel & 638 & $50,27 \%$ \\
Cedido & 44 & $3,46 \%$ \\
Em obras & 41 & $5,35 \%$ \\
Fechado & 68 & $1,18 \%$ \\
O utros & 15 & $36,40 \%$ \\
Próprio & 462 & \\
Total & 1.269 & $10,90 \%$ \\
\hline Uso & & $86,78 \%$ \\
Comercial & 26 & \\
M isto & 132 & \\
Residencial & 1.051 & \\
Total & 1.211 & \\
\hline
\end{tabular}

Fonte: Livro da Décima de 1809. Arquivo do Estado de São Paulo.

Q uanto à destinação, dos 1.269 imóveis a rrolados nesse item, 638 $(50,27 \%)$ eram de aluguel; $462(36,40 \%)$ de uso próprio; $44(3,46 \%)$ encontravam-se cedidos de favor; 68 (5,35\%) estavam fechados; $41(3,23 \%)$ em obras; e $15(1,18 \%)$ não foram taxados por serem considerados "insignificantes", "a rruina dos" ou por esta rem "em conserto" (Figura 2). 


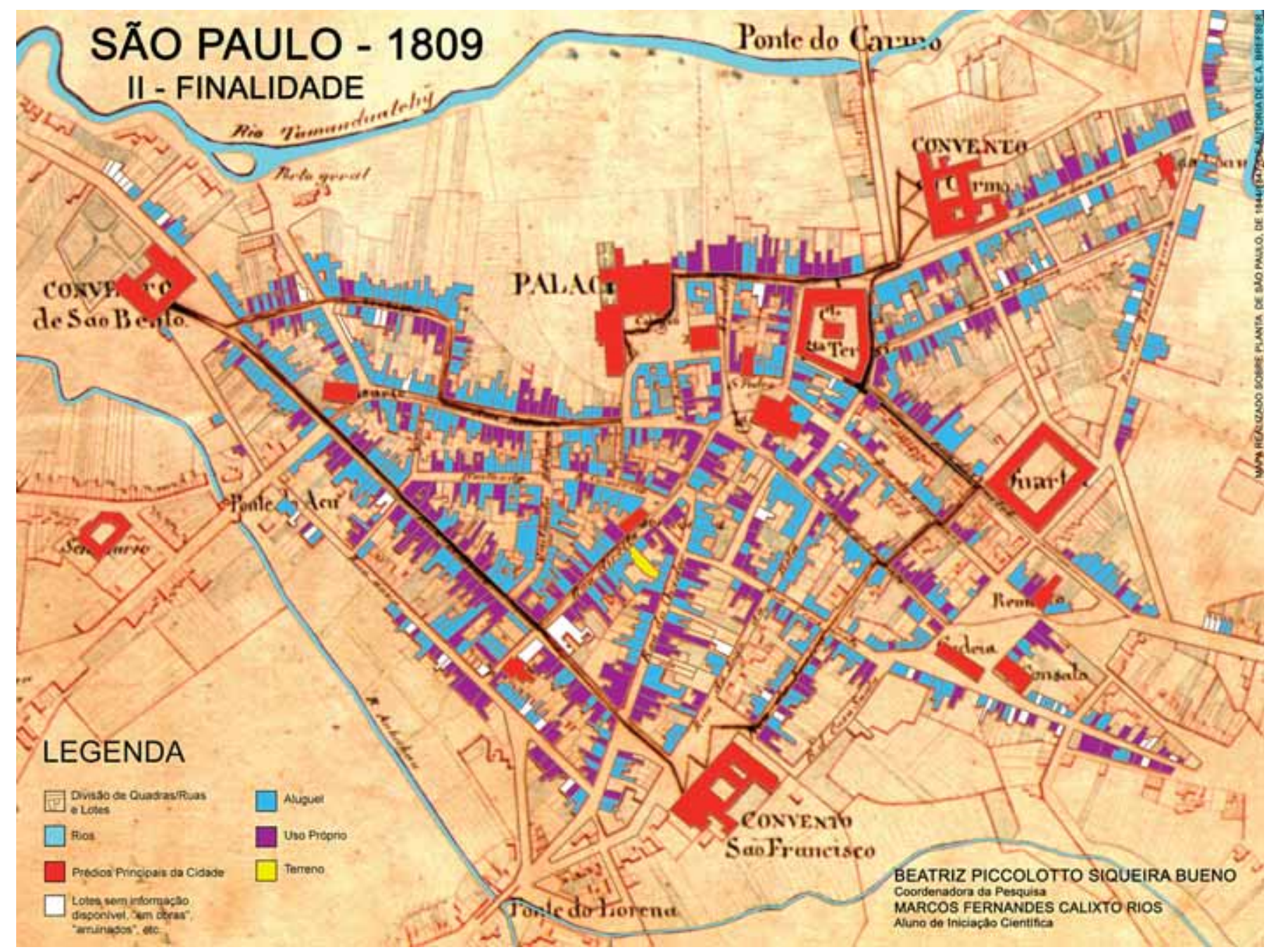

Figura 2 - Prancha II - Finalidade. Autora: Beatriz P. Siqueira Bueno. M apa-base: "Mappa da Cidade de São Paulo offerecido a Sua Magestade, o Imperador pelo Presidente da Província Manoel da Fonseca Lima e Silva (1844-1847)", do Engenheiro Carlos Bresser, datável de 1844-1847. Seção de Cartografia da Fundação Biblioteca N acional, Rio de Janeiro. 
$10 \%$ do imposto era embolsado pelo Coronel Luiz Antonio de Souza, encarregado de supervisionar a sua cobrança em São Paulo.
M uitos imóveis de aluguel a presentavam vários inquilinos, por exemplo quando se tratava de uma casa térrea de vários lanços (um inquilino por lanço) ou sobrados de uso misto com mais de uma loja.

Esses dad os contra riam a visão corrente da histo riog rafia que considera o investimento em casas de aluguel uma tônica apenas do último quartel século XIX. Segundo Raquel Rolnik:

A construção de salas e casas para alugar cresceu no começo da década de 1870, ainda que muito antes, junto com os grandes sobrados, já marcassem a paisagem do Triângulo. Em 1822, o viajante Auguste de Saint-Hilaire comentava sobre a existência de casas e salas para alugar: pequenas construções muito baixas de barro e paredes de sarrafo, com tetos cadentes, chãos de pisos sujos nos trechos mais pobres das ruas São Francisco, Rosário ou Boa Vista. Muitas ficavam ao lado dos grandes sobrados; é o caso da esquina da rua do Rosário com a Travessa do Colégio e da Senador Vergueiro com a rua Direita, no coração do triângulo central.

Evid entemente a dimensão desse tipo de investimento era bastante restrita, considerando sobretudo o número irrisório de consumidores potenciais - assalariados não proprietários - em um contexto onde imperava o trabalho escravo. Estes, desprovidos de recursos para adquirir um abrigo próprio, mesmo sem vínculos compulsórios com as casas senhoriais, moravam muitas vezes "de favor", ou sem pagar nada em casas ou cubículos de propriedade das famílias abastadas. Maria 0 dila Dias relata grande número de casos em que exescravos herdaram pequenas casas de morar de seus senhores, ou de homens e mulheres livres e pobres vinculados às casas senhoriais por redes de compadrio ou serviço que habitavam não no interior das casas grandes, mas em casinhas cedidas em suas proximidades" (2003, p. 102).

Subestimando o número de casas de aluguel no tecido urbano, Raquel Rolnik insinua que muitos viviam de favor. Ao contrário do que disse a autora, contabilizamos apenas $3 \%$ de moradias cedidas nessa condição em oposição a $50 \%$ de casas alugadas.

O bservamos que as verificações de M aria 0 dila da Silva Dias são verdadeiras, já que boa parte das casas cedidas de favor o eram a parentes próximos ou ex-escravos. No entanto, a o contrário do que a firma Rolnik, numa sociedade escravista, havia sim setores médios de não proprietários capazes de alimentar um mercado locatício bastante intenso.

As tab elas seguintes, referentes à distribuição da população por g rupos ocupacionais, em 1818, e aos profissionais recenseados na cidade de São Paulo, em 1593, 1793, 1836, podem nos dar uma idéia das camadas médias existentes no cenário urbano da cidade de São Paulo nesse período. 


\begin{tabular}{|c|c|}
\hline \multicolumn{2}{|c|}{$\begin{array}{c}\text { Cidade de São Paulo: distribuição da população } \\
\text { por grupos ocupacionais em } 1818\end{array}$} \\
\hline G rupos ocupacionais & $\mathrm{N}$ úmeros \\
\hline Corpo militar & 566 \\
\hline M ag istra do & 1 \\
\hline Clero secular & 81 \\
\hline Clero regular & 14 \\
\hline Religiosos recolhidos & 56 \\
\hline Agricultores & 1.640 \\
\hline N egociantes & 220 \\
\hline Artistas & 277 \\
\hline Jorna leiros & 98 \\
\hline Condutores & 52 \\
\hline Madeireiros & 18 \\
\hline M ineiros & 1 \\
\hline M endigos ${ }^{1}$ & 152 \\
\hline Total & 3.176 \\
\hline
\end{tabular}

Fonte: M O RSE, R. Formação histórica de São Paulo. Apud M EM Ó RIA URBAN A, 2001.

(1) Incluindo mendigos mas não escravos. 
Cidade de São Paulo:

profissionais recenseados

\begin{tabular}{|c|c|c|c|}
\hline $\begin{array}{l}\text { A tividades } \\
\text { profissionais }\end{array}$ & 1593 & 1793 & 1836 \\
\hline Carpintaria & 2 & 10 & 77 \\
\hline Sapataria (oficina) & 1 & 16 & 69 \\
\hline Ferra ria & 1 & 4 & 54 \\
\hline A lfaia ta ria & 2 & 21 & 49 \\
\hline O laria & 1 & 4 & 38 \\
\hline 0 urivesa ria & - & - & 30 \\
\hline M arcenaria & - & - & 28 \\
\hline Selaria & - & 4 & 13 \\
\hline Pintura & - & - & 10 \\
\hline La ta ria & - & - & 7 \\
\hline Construção & - & 4 & 7 \\
\hline Padaria & - & - & 7 \\
\hline Botica & - & - & 7 \\
\hline Const de violas & - & - & 6 \\
\hline Barbearia & - & 6 & 6 \\
\hline Entalhe & - & - & 3 \\
\hline Tecelagem & 2 & - & 3 \\
\hline Tanoaria & - & - & 2 \\
\hline Serra ria & - & - & 2 \\
\hline Cald eira ria & - & - & 2 \\
\hline Chapelaria (oficina) & - & - & 2 \\
\hline Fábrica de foguetes & - & - & 2 \\
\hline Sirga & - & - & 2 \\
\hline Relojoaria & - & - & 1 \\
\hline Total & 9 & 69 & 427 \\
\hline
\end{tabular}

Fonte: Aspectos da M etrópole Paulista. In: AZEVEDO, A. (org.). A cidade de São Paulo - estudos de geografia urbana. Apud M EM Ó RIA URBAN A, 2001. 
Alguns outros dados saltam à vista quando analisamos o Livro da Décima Urbana de 1809 . Por exemplo, o valor total atribuído a imóvel número 1 da Rua Direita - 71\$440rs - é praticamente igual ao do aluguel anual do imóvel vizinho - 50\$000rs -, tipologicamente idêntico (um sobrado de uma loja e um primeiro andar):

\section{Freguezia da Sé - Rua Direita Lado Esquerdo}

N 0. 1 Propriedade de cazas do G uarda-mor Vicente Ferreira de 0 liveira, que consta de huma logea, e hum primeiro andar, q foi avaliada em setenta e hum mil quatrocentos e quarenta, de q abatidos dez por cento vem para a Décima sinco mil quinhentos e vinte nove reis, com que sahe $5 \$ 529$.

N 0. 2 Propriedade do Reverendo Bartholomeu Pereira M endes, que consta de huma logea e hum primeiro andar, e da qual he Inquilino o Capitão Antonio Jozé Brito, que jurou ter alugado annualmente pela quantia de cincoenta mil reis, de que vem para a décima quatro mil e quinhentos reis com que sae $4 \$ 500$.

$\mathrm{N}$ esse aspecto, provavelmente era o potencial locatício anual 0 o rientador do valor a tribuído a o imóvel, em caso de venda, num mercado imobiliário de base rentista como esse.

Q uanto aos usos, $86,78 \%$ do tecido urbano eram compostos de imóveis residenciais; $2,14 \%$ exclusivamente comerciais e $10,90 \%$ de uso misto (Figura 3). 0 u seja, de um total de 1.211 imóveis cadastrados nessa categoria, 1.051 eram residenciais, 26 comerciais e 132 de uso misto.

São Paulo, em 1809, era portanto uma cidade predominantemente térrea, residencial e com boa parte dos seus habitantes vivendo em casas alugadas.

Tratava-se de uma cidade concentrada e com espaços pouco especializados, na qual as principais funções urbanas - residência, comércio, serviços, instituições civis e religiosas - mesclavam-se numa mesma área.

Ta mbém era uma cidade pouco complexa na medida em que seu tecido urbano se definia a partir da relação entre edifícios privados (casas, lojas, igrejas de irmandades laicas e ordens terceiras - restritas a os seus membros -, conventos, mosteiro) e públicos oficiais (Palácio dos G overnadores, Casa de Câmara e Cadeia, Q uartel das Tropas de M ilitares, Casa de Fundição, etc.), em meio a espaços públicos de uso coletivo como ruas e largos. Em termos de infra estrutura, os esforços da administração pública concentra vam-se nas pontes que davam acesso à colina, no calçamento de certas vias e largos e no abastecimento de água por meio de fontes e chafarizes.

Embora constrangida na colina histórica, com espaços pouco especializados, públicos de uso coletivo ou privados, em 1809 , a presentava áreas mais e menos valorizadas em termos imobiliários. Espécie de esquema centrípeto, as zonas mais caras eram aquelas junto aos Largos da Sé, Largo do 


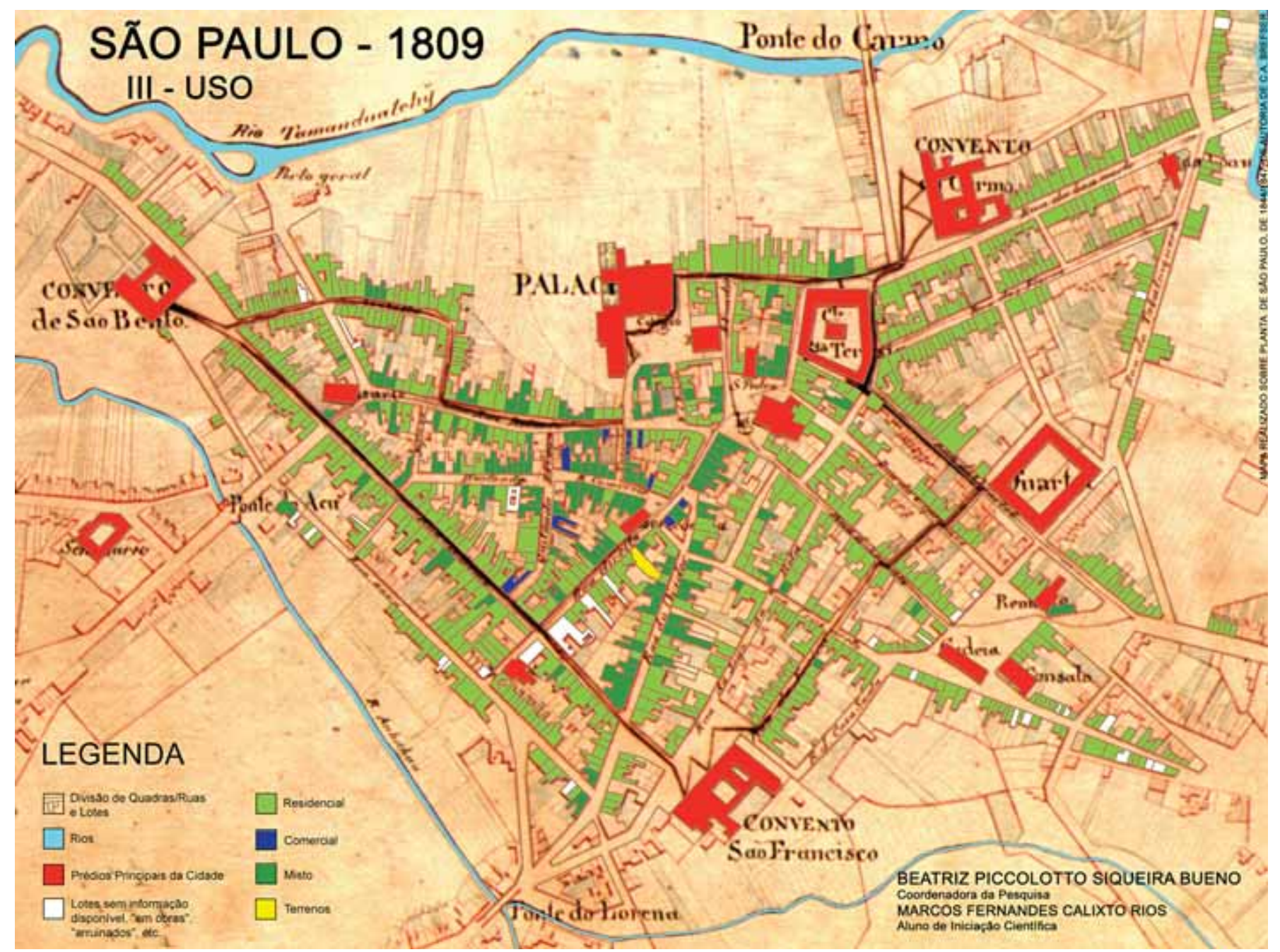

Figura 3 - Prancha III - Usos. Autora: Beatriz P. Siqueira Bueno. Mapa-base: "Mappa da Cidade de São Paulo offerecido a Sua Magestade, o Imperador pelo Presidente da Província Manoel da Fonseca Lima e Silva (1844-1847)", do Engenheiro Carlos Bresser, datável de 1844-1847. Seção de Cartografia da Fundação Biblioteca N acional, Rio de Janeiro. 
Palácio (atual Pátio do C olégio) e ruas de uso misto a eles contíguas, concentrando o comércio da cidade.

Segundo listagem fornecida pelo banco de dados, os imóveis mais caros encontravam-se situados nas Ruas do Carmo, do Comércio, na Tra vessa das C asinhas, Rua do Rosário, Rua Direita, Rua de S. Bento, Rua do 0 uvidor, Rua da Boa Vista e Rua de S. Teresa (Figura 4 ).

Em contrapartida, os imóveis mais ba ratos ficavam junto das várzeas ou a lém rios. $\mathrm{N}$ a Rua do Piques oscilavam entre $1 \$ 440$ rs e $1 \$ 200$ rs; na Rua de Santa Ifigênia também; na Rua da Luz $1 \$ 200$ rs; nas Ruas do Rego, da Cachoeira e do Tanque (junto a o Tanque do Zuniga, na Freguesia de S. Ifigênia) variavam de $\$ 120$ rs a $1 \$ 000$ rs.

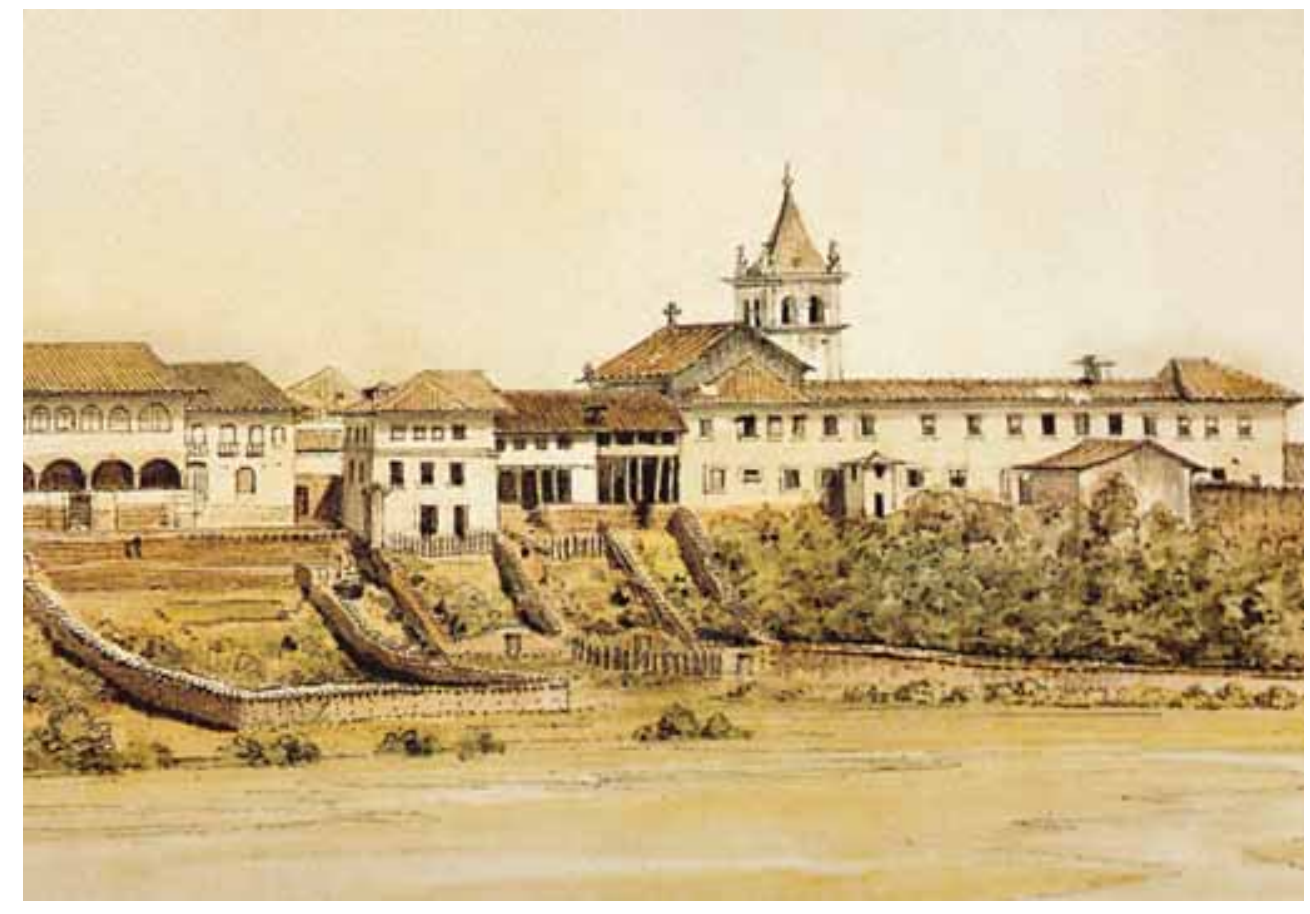

Figura 4 - A cidade de São Paulo vista da várzea do Carmo - parte $\mathrm{N}$ orte. A rnaud Julien Pallière, 1821. Coleção Beatriz e M ário Pimenta Camargo. Reprodução fotográfica a partir de REIS FILHO , 2004, p. 92-94. O bservar os quinta is murados e as fachadas posteriores dos sobrados da antiga R. de S. Teresa (atual Roberto Simonsen). À direita, destacam-se as arcadas do futuro sobrado da Marquesa dos Santos, em 1809, ainda pertencente ao Coronel Joaquim Jozé Pinto de Moraes. 
O s dez imóveis mais caros de São Paulo em 1809

Logradouro

Imóvel

Valor (Réis)

Rua do Carmo, 49

Sobrado de dois lanços e um andar propriedade do testamenteiro de D. Francisca de Mattos

Rua do Comércio, 25

Sobrado de cinco lojas e um andar propriedade de D. Anna de Almeida

Travessa das C asinhas, 8

Sobrado de duas lojas e um andarpropriedade de Jozé Pinto Tavares

Rua do Rosário a Boa Vista, 13 Sobrado de cinco lojas e um andar propriedade de Joaquim Jozé da Silva

Rua do Comércio, 7 Sobrado de quatro lojas e um andar propriedade de Luiz G onzaga de Araújo

Travessa das C asinhas, 2 Sobrado de três lojas e um andar propriedade de Jozé Amaro de Camargo

Rua Direita, 1

Sobrado de uma loja e um andar propriedade do G uarda-mor Vicente Ferreira de 0 liveira

Rua de São Bento, 85

Sobrado de um lanço, três lojas e 1 andar - propriedade de Felisberto Pedrozo Siqueira

Rua do 0 uvidor, 37

Sobrado de dois lanços e um andar propriedade de Antonio Jozé Barboza Inquilino:C âmara )

Rua Direita, $6 \quad$ Sobrado de uma loja e um andar propriedade do M osteiro de São Bento)

Rua de São Bento, 28

Sobrado de seis lojas e um andar propriedade do Reverendo $M$ anuel Francisco de Andrade

Rua Boa Vista, 37

Casa térrea de dois lanços - propriedade

de João Soares de Figueiredo

Cardozo Barbas

Rua Direita, 2

Sobrado de uma loja e um andar propriedade do Reverendo Bartholomeu Pereira M endes

Fonte: Livro da Décima de 1809. Arquivo do Estado de São Paulo.

A casa mais valorizada, em 1809 , era 853 vezes mais cara que a menos valorizada; a primeira situando-se numa das principa is ruas residencia is - a Rua do Carmo - , junto da Rua de S. Tereza (atual Roberto Simonsen); a outra nas bordas do perímetro urbano. Seria o equivalente a compararmos a residência de Josef Safra, aproximadamente avaliada em torno de $\mathrm{R} \$ 30$ milhões, com a 
casa de um mutirão, a valiada em torno de $\mathrm{R} \$ 10$ mil; hoje a diferença oscilaria em 3.000 vezes.

$\mathrm{N}$ as devidas proporções, com dinâmicas urbanas extremamente diversas, a cidade de 1809 e a de 2005 parecem esboçar uma tônica recorrente da história da urbanização brasileira, a da segregação social nos espaços urbanos. Malgrado pouco especializado, o espaço intra-urbano da cidade colonial, embora aparentemente mais democrático, configurava no seu tecido uma nítida segregação social e espacial dos menos favorecidos.

Havia uma concentração de sobrados nas Ruas Direita, do 0 uvidor, do Comércio, do Rosário, de São Bento, de Santa Tereza, do Carmo, no Largo da Sé e no Largo do Colégio, tratando-se da área nobre da cidade. À exceção das Ruas do Carmo e de Santa Tereza, predominantemente residenciais, as dema is sup racitadas caracterizavam-se por um conjunto significativo de imóveis de uso misto ou exclusivamente comerciais. $\mathrm{N}$ as extremidades, distribuía-se um casario térreo e residencial (Figuras 1 e 3 ).

Ao contrário da concentração verificada quanto às tipologias e usos, observamos que se misturavam no tecido urbano os imóveis de uso próprio e aqueles de a luguel (Figura 2 ).

De um total de 1.281 imóveis cadastrados:

- 1.041 eram propriedades de leigos;

- 233 distribuíam-se nas mãos das ordens religiosas;

- 41 pertenciam às irmandades;

- 192 aos padres seculares.

Dos 748 proprietários registrados, o Mosteiro de São Bento possuía 61 imóveis; o Dr. Antonio Soares Calheiros, 24; o Convento do Carmo, 22; 0 Coronel Jozé Arouche de Toledo, 18; o Recolhimento de Santa Tereza, 15; a Irmandade de São G onçalo, 14; 0 C apitão M a nuel da Luz Tralhão e o C a pitão Antonio Alvarez dos Reis, 13; o Capitão Gabriel Jozé Roiz ,11; a Câmara de São Paulo, D. Mariana Fortes e Jozé Antonio da Silva Paulista, 10; a Irmandade do Rosário dos Pretos, nove; o C oronel Anastácio de Freitas Trancozo, oito; 0 Coronel Luiz Antonio de Souza, o Coronel Jozé Vaz de Carvalho, Dionizio Ereopagita e o Reverendo Ignácio Francisco de Moraes, sete. Dos demais proprietários, seis possuíam seis imóveis; dez dispunham de cinco imóveis; 19 detinham quatro imóveis; 34 eram proprietários de três imóveis e 86 de a té dois imóveis.

Portanto, dos 748 proprietários a rrolados, a penas 24 detinham cerca de $1 / 4$ (302 imóveis) dos 1.281 inventariados, configurando uma enorme concentração de prédios urbanos nas mãos de poucos; algo muito semelhante aos dias atuais. Um total de 173 proprietários detinham mais de dois imóveis e 575 apenas um imóvel.

$\mathrm{N}$ em sempre quantidade significa va qualidade. 0 s 20 proprietá rios com mais capital investido em imóveis na cidade de São Paulo, em 1809, nem sempre eram os detentores da maior quantidade de unidades. A localização mais central, junto às ruas comerciais ou à Sé, garantia melhores preços aos imóveis (Figura 5 ). 


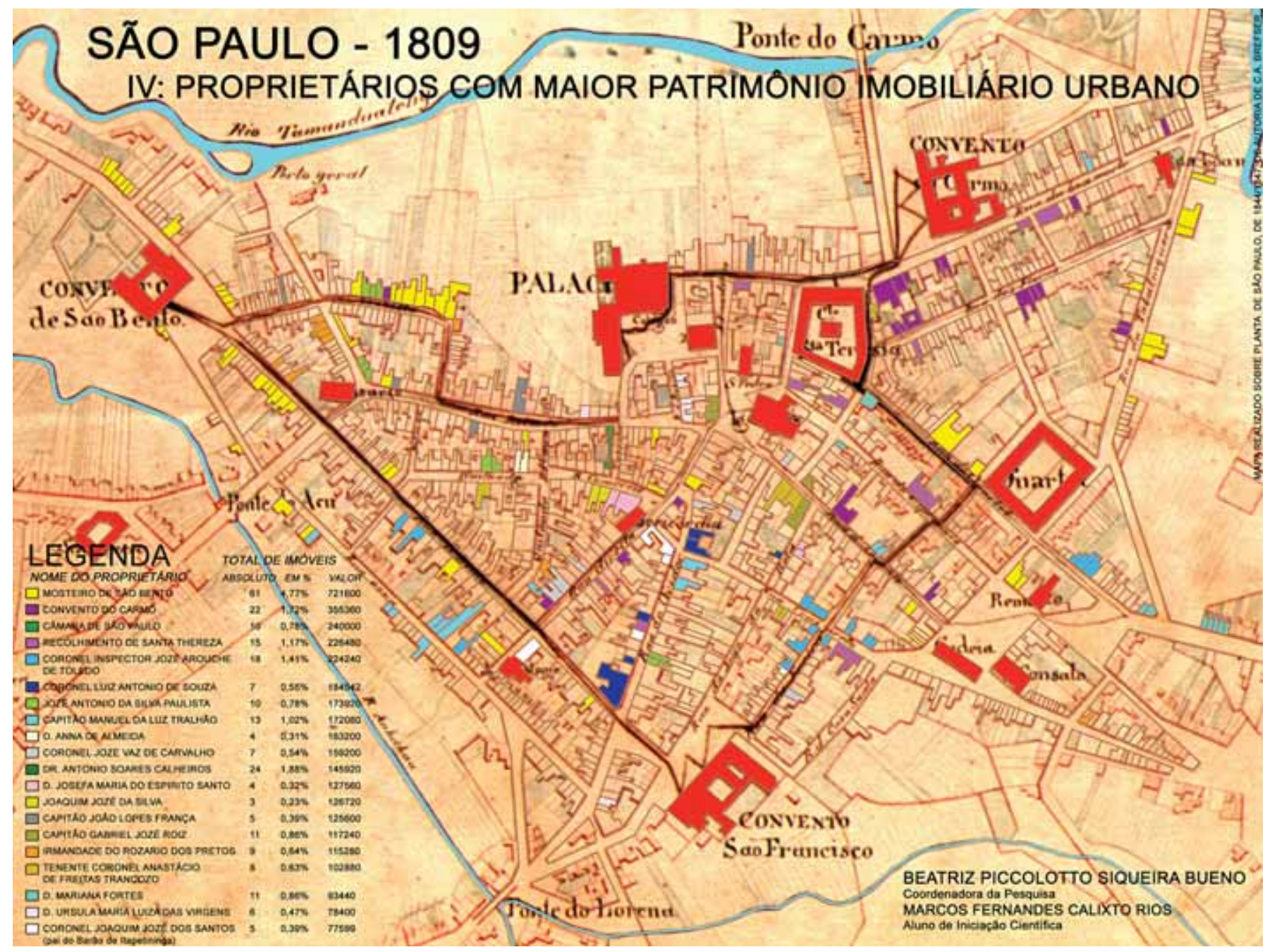

Figura 5 - Espacialização dos imóveis pertencentes aos 20 proprietários detentores de maior patrimônio imobiliário urbano em São Paulo, em 1809. Autora: Beatriz P. Siqueira Bueno. Mapa-base: "Mappa da Cidade de São Paulo offerecido a Sua Magestade, - Imperador pelo Presidente da Província Manoel da Fonseca Lima e Silva (1844-1847)", do Engenheiro Carlos Bresser, datável de 1844 -1847. Seção de C artografia da Fundação Biblioteca N acional, Rio de Janeiro. 
Os 20 proprietários detentores de maior patrimônio imobiliário urbano em São Paulo em 1809 (percentual de propriedades sobre o total de imóveis da cidade)

\begin{tabular}{lccc}
\hline PRO PRIETÁ RIO & QUAN TIDADE & PERCEN TUAL & VALOR R (RÉIS) \\
\hline M osteiro de São Bento & 61 & $4,77 \%$ & $721 \$ 600$ \\
\hline Convento do C armo & 22 & $1,72 \%$ & $355 \$ 360$ \\
\hline Câmara de São Paulo & 10 & $0,78 \%$ & $240 \$ 000$ \\
\hline Recolhimento de Santa Thereza & 15 & $1,17 \%$ & $226 \$ 480$ \\
\hline Coronel-inspetor José Arouche de Toledo & 18 & $1,41 \%$ & $224 \$ 240$ \\
\hline Coronel Luiz Antonio de Souza & 7 & $0,55 \%$ & $184 \$ 542$ \\
\hline José Antonio da Siva Paulista & 10 & $0,78 \%$ & $173 \$ 920$ \\
\hline Capitão M anuel da Luz Tralhão & 13 & $1,02 \%$ & $172 \$ 080$ \\
\hline D. Anna de Almeida & 4 & $0,31 \%$ & $163 \$ 200$ \\
\hline Coronel Joze Vaz de C arvalho & 7 & $0,54 \%$ & $159 \$ 200$ \\
\hline Dr. Antonio Soares C alheiros & 24 & $1,88 \%$ & $145 \$ 920$ \\
\hline D. Josefa M aria do Esprito Santo & 4 & $0,32 \%$ & $127 \$ 560$ \\
\hline Joaquim Jozé da Silva & 3 & $0,23 \%$ & $126 \$ 720$ \\
\hline Capitão João Lopes França & 5 & $0,39 \%$ & $125 \$ 600$ \\
\hline Capitão G abriel José Roiz & 11 & $0,86 \%$ & $117 \$ 240$ \\
\hline Irmandade do Rozario dos Pretos & 9 & $0,64 \%$ & $115 \$ 280$ \\
\hline Tenente Coronel Anastácio & 11 & $0,86 \%$ & $93 \$ 440$ \\
\hline De Freitas Trancozo & 6 & $0,47 \%$ & $78 \$ 400$ \\
\hline D. M arianna Fortes & 5 & $0,39 \%$ & $77 \$ 599$ \\
\hline Coronel Joaquim Jozé dos Santos & & $0,63 \%$ & $102 \$ 880$ \\
\hline
\end{tabular}


Listagem dos principais prop rietários urbanos

(percentual de propriedades sobre o total de imóveis da cidade)

\begin{tabular}{|c|c|c|c|}
\hline PRO PRIETA RIO & Q UAN TIDADE & PERCEN TUAL & VALO R (RÉIS) \\
\hline \multicolumn{4}{|l|}{ LEIGOS } \\
\hline Câmara de São Paulo & 10 & $0,78 \%$ & $240 \$ 000$ \\
\hline $\begin{array}{l}\text { Coronel/ Inspetctor } \\
\text { Jozé Arouche de Toledo }\end{array}$ & 18 & $1,41 \%$ & $224 \$ 240$ \\
\hline Coronel Luiz Antonio de Souza & 7 & $0,55 \%$ & $184 \$ 542$ \\
\hline Jozé Antonio da Silva Paulista & 10 & $0,78 \%$ & $173 \$ 920$ \\
\hline Capitão M anuel da Luz Tralhão & 13 & $1,02 \%$ & $172 \$ 080$ \\
\hline D. Anna de Almeida & 4 & $0,31 \%$ & $163 \$ 200$ \\
\hline Dr. Antonio Soares C alheiros & 24 & $1,88 \%$ & $145 \$ 920$ \\
\hline Joaquim Jozé da Silva & 3 & $0,23 \%$ & $126 \$ 720$ \\
\hline Capitão João Lopes França & 5 & $0,39 \%$ & $125 \$ 600$ \\
\hline Capitão G abriel Jozé Roiz & 11 & $0,86 \%$ & $117 \$ 240$ \\
\hline $\begin{array}{l}\text { Tenente-C oronel Anastácio } \\
\text { de Freitas Trancozo }\end{array}$ & 8 & $0,63 \%$ & $102 \$ 880$ \\
\hline D. M arianna Fortes & 11 & $0,86 \%$ & $93 \$ 440$ \\
\hline Coronel Francisco Xavier dos Santos & 6 & $0,47 \%$ & $92 \$ 160$ \\
\hline D. Josefa M aria do Espirito Santo & 2 & $0,16 \%$ & $89 \$ 160$ \\
\hline Coronel Joze Vaz de Carvalho & 3 & $0,23 \%$ & $83 \$ 360$ \\
\hline D. Ursula M aria Luiza das Virgens & 6 & $0,47 \%$ & $78 \$ 400$ \\
\hline Coronel Joaquim Jozé dos Santos & 5 & $0,39 \%$ & $77 \$ 599$ \\
\hline Coronel Jozé Vaz de Carvalho & 4 & $0,31 \%$ & $75 \$ 840$ \\
\hline M a nuel Lopes Coimbra & 3 & $0,23 \%$ & $73 \$ 600$ \\
\hline Joaquim Jozé de 0 liveira & 6 & $0,47 \%$ & $72 \$ 960$ \\
\hline Capitão Antonio Alvarez dos Reis & 13 & $1,02 \%$ & $69 \$ 430$ \\
\hline Dionizio Ereopagita & 7 & $0,55 \%$ & $69 \$ 200$ \\
\hline Clara de Souza & 6 & $0,47 \%$ & $66 \$ 540$ \\
\hline D. Anna Leoniza de Abelho Fortes & 6 & $0,47 \%$ & $66 \$ 300$ \\
\hline Luiz G onzaga de Araújo & 1 & $0,08 \%$ & $63 \$ 900$ \\
\hline Jozé Amaro de Camargo & 1 & $0,08 \%$ & $63 \$ 360$ \\
\hline $\begin{array}{l}\text { Coronel-Engenheiro João } \\
\text { da Costa Ferreira }\end{array}$ & 2 & $0,16 \%$ & $62 \$ 400$ \\
\hline
\end{tabular}




\begin{tabular}{|c|c|c|c|}
\hline G uarda-M or Vicente Ferreira de 0 liveira & 1 & $0,08 \%$ & $61 \$ 440$ \\
\hline Felisberto Pedroso Siqueira & 1 & $0,08 \%$ & $60 \$ 000$ \\
\hline $\begin{array}{l}\text { Herdeiros do Coronel } \\
\text { Joaquim M anuel da Silva }\end{array}$ & 4 & $0,31 \%$ & $59 \$ 520$ \\
\hline D. Caetana de Toledo & 4 & $0,31 \%$ & $55 \$ 320$ \\
\hline D. Caetana de Toledo e suas irmãs & 3 & $0,23 \%$ & $53 \$ 960$ \\
\hline $\begin{array}{l}\text { Dr. M iguel Carlos } \\
\text { (N ovo Fiscal da Décima) }\end{array}$ & 2 & $0,16 \%$ & $30 \$ 720$ \\
\hline Dr. N icolao Pereira de Campos Vergueiro & 1 & $0,08 \%$ & $30 \$ 720$ \\
\hline Jaime da Silva Telles & 4 & $0,31 \%$ & $28 \$ 160$ \\
\hline \multicolumn{4}{|l|}{ REUGIOSOS } \\
\hline M osteiro de São Bento & 61 & $4,77 \%$ & $721 \$ 600$ \\
\hline Convento do Carmo & 22 & $1,72 \%$ & $355 \$ 360$ \\
\hline Recolhimento de Santa Thereza & 15 & $1,17 \%$ & $226 \$ 480$ \\
\hline Irmandade do Rozario dos Pretos & 8 & $0,63 \%$ & $105 \$ 680$ \\
\hline Irmandade de São Pedro & 3 & $0,23 \%$ & $82 \$ 880$ \\
\hline Reverendo Ignácio Francisco de Moraes & 7 & $0,55 \%$ & $79 \$ 360$ \\
\hline Irmandade de São G onçalo & 14 & $1,09 \%$ & $68 \$ 360$ \\
\hline Reverendo Bartholomeu Pereira M endes & 3 & $0,23 \%$ & $65 \$ 360$ \\
\hline Reverendo M anuel Francisco de Andrade & 2 & $0,16 \%$ & $61 \$ 520$ \\
\hline Irmandade das Almas & 3 & $0,23 \%$ & $56 \$ 320$ \\
\hline Irmandade do Santíssimo Sacramento & 4 & $0,31 \%$ & $47 \$ 040$ \\
\hline $\begin{array}{l}\text { Irmandade do Santíssimo } \\
\text { Sacramento -Vila de Santos }\end{array}$ & 1 & $0,08 \%$ & $31 \$ 000$ \\
\hline Irmandade do Sr. Jezus de $\mathrm{N}$ aza reth & 1 & $0,08 \%$ & $25 \$ 200$ \\
\hline Irmandade do Rozario dos Brancos & 3 & $0,23 \%$ & $21 \$ 120$ \\
\hline Irmandade dos Remédios & 1 & $0,08 \%$ & $20 \$ 480$ \\
\hline M osteiro de São Bento de Parnahiba & 3 & $0,23 \%$ & $19 \$ 800$ \\
\hline Mosteiro de São Bento de Sorocaba & 1 & $0,08 \%$ & $12 \$ 000$ \\
\hline Irmandade dos Passos do C armo & 1 & $0,08 \%$ & $8 \$ 000$ \\
\hline Irmandade de Santa Efigênia & 1 & $0,08 \%$ & $7 \$ 680$ \\
\hline O rdem Terceira do C armo & 1 & $0,08 \%$ & $3 \$ 840$ \\
\hline O rdem Terceira de São Francisco & 1 & $0,08 \%$ & $2 \$ 400$ \\
\hline
\end{tabular}

Fonte: Livro da Décima de 1809. Arquivo do Estado de São Paulo. 
Assim como no Rio de Janeiro, os beneditinos ocupavam posição de destaque, dispondo de significativo patrimônio imobiliário urbano, na sua maioria casas térreas de um lanço, construídas para renda de aluguel, que em média eram a lugadas por $12 \$ 000 \mathrm{rs}$, chegando a atingir a cifra dos $19 \$ 000 \mathrm{rs}$ nas melhores localizações. Também se destacaram como empresários urbanos no perío do colonial, construindo conjuntos de casas de aluguel na área envoltória aos mosteiros, envolvendo inclusive projetos aprovados pelos superiores hierárquicos da 0 rdem, sediada no M osteiro de Tibães, em Braga. Em São Paulo, em 1787, foi construído um conjunto de casas de aluguel pelos monges no trecho inicial da atual Rua Florêncio de Abreu, indicado na época como "Rua N ova de São Bento, chamada Rua da Alegria" (REIS FILHO, 2004, p. 78-79). 0 projeto, hoje, encontra-se localizado no Arquivo Distrital de Braga (Figura 6). Sabemos que as casinhas de aluguel foram construídas, pois figuram na imagem de Pallière, referente a São Paulo, em 1821. N a lateral do mosteiro, observase o portão de acesso à várzea do Ta mandua teí e os quintais mura dos de algumas das casas (Figura 7 ).

$\mathrm{N}$ o Rio de Janeiro, os beneditinos foram responsáveis por conjuntos de moradias de aluguel de natureza semelhante. $\mathrm{N}$ a também recém-aberta Rua $\mathrm{N}$ ova de São Bento (atual Rua do Q uartel de Bragança, hoje, Conselheiro

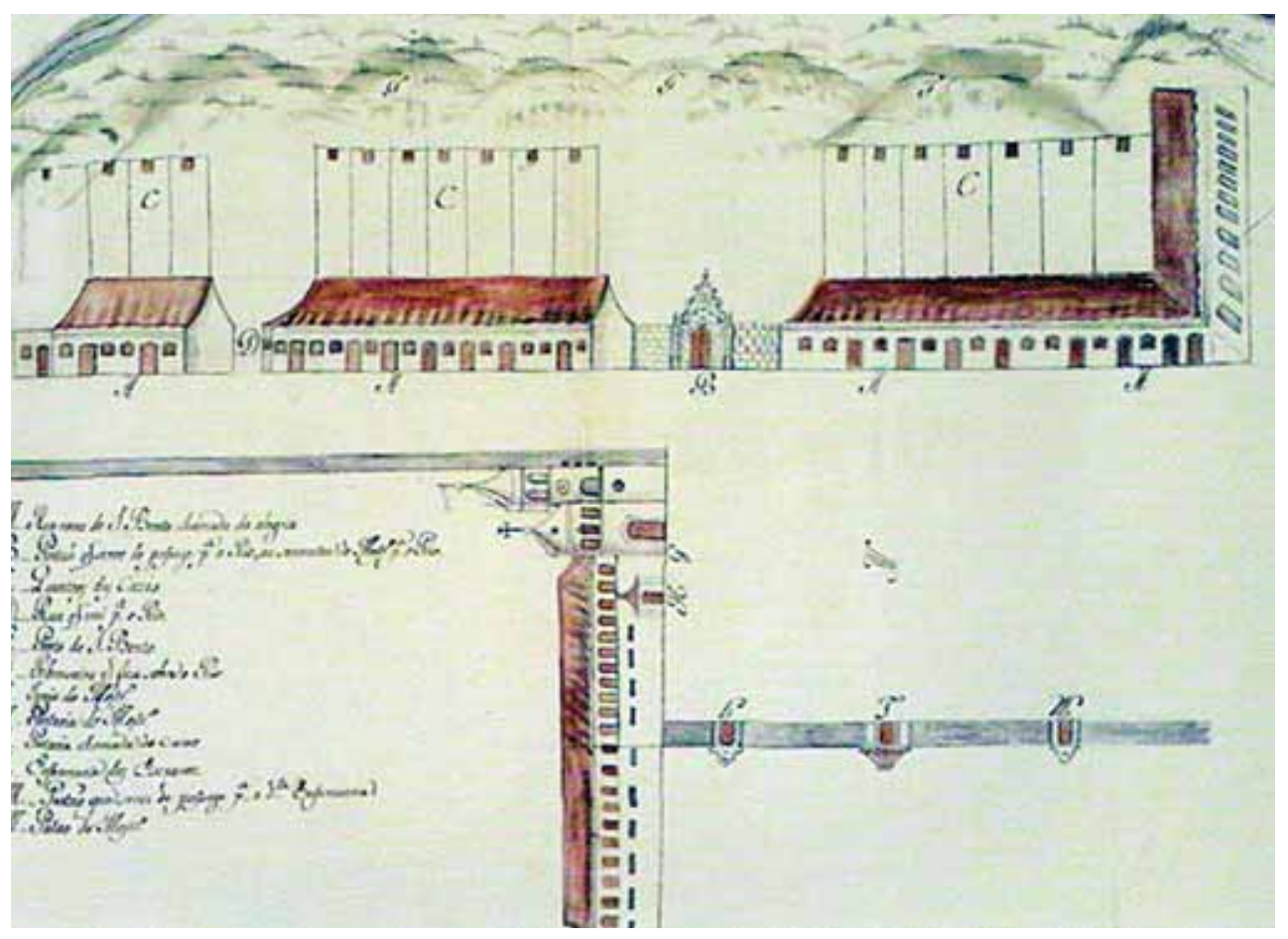

Figura 6 - Projeto de casas de aluguel construídas pelos beneditinos nas imediações do Mosteiro. Autor: desconhecido, data: 1787. Arquivo Distrital de Braga/ Universidade do M inho - Portugal. Reprodução fotográfica a partir de REIS FILHO, 2004, p. 78. 


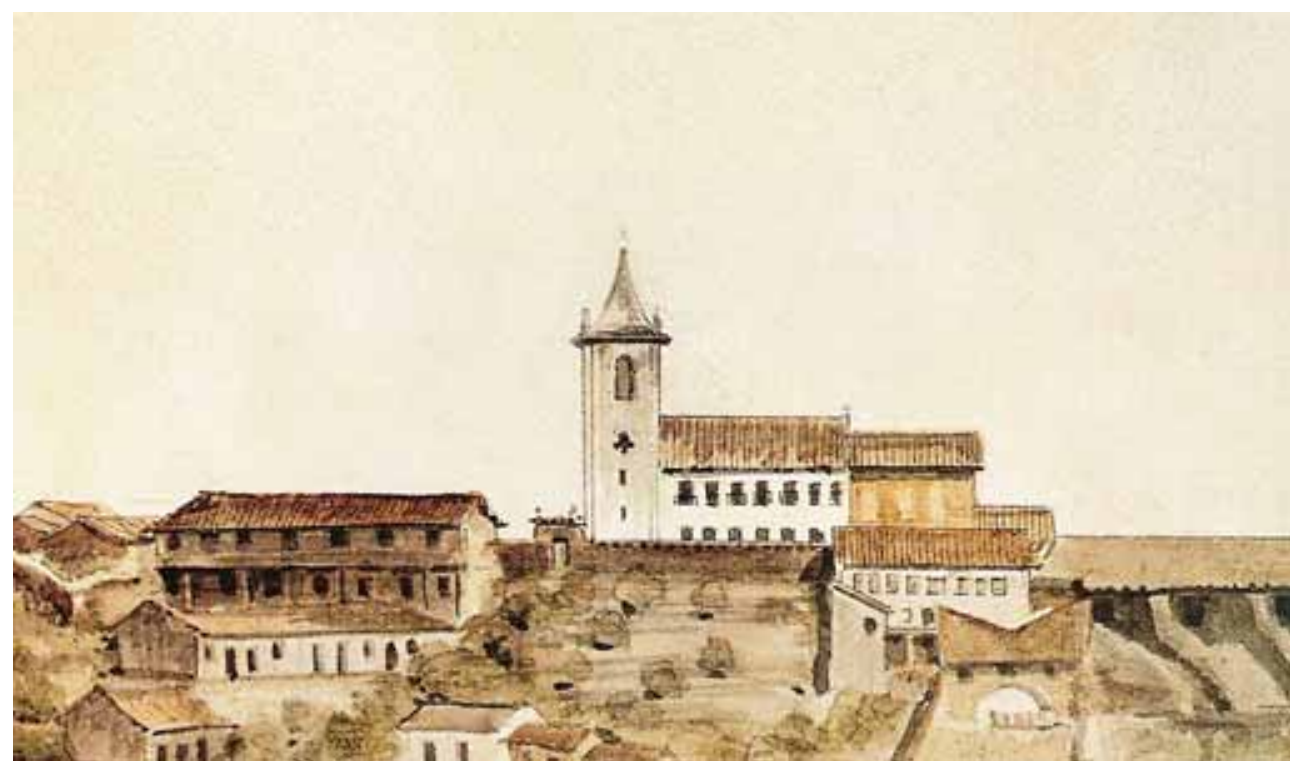

Figura 7 - A cidade de São Paulo vista da várzea do Carmo - parte N orte. A rnaud Julien Pallière, 1821. Coleção Beatriz e M ário Pimenta Camargo. O bservar, à esquerda e à direita do portão de acesso à várzea, os fundos das casas de aluguel dos beneditinos, projetadas em 1787 .

Saraiva), os beneditinos construíram um conjunto de casas de aluguel, de ambos os lados, contratando para tanto os mestres carpinteiros Bento Coelho e Francisco Rabelo de Almeida, que seguiram o "risco" assinado pelos monges. Como menciona $\mathrm{N}$ ireu Cavalcanti, tratava-se de um comitente qualificado, espécie de empresário urbano do período colonial, com longa experiência em construção, possuidor de pedreiras e olarias que abasteceriam o canteiro de obras. Tratavase também de uma obra complexa, abrangendo a abertura de um logradouro e construção, em ambos os lados, de prédios térreos e sobrados, num período previsto de quatro anos, cabendo a os mestres carpinteiros a edificação de "todas as moradas de casas". Sem dúvida, para a época, correspondia a um ousado empreendimento imobiliário realizado por uma instituição particula r, com recursos próprios, voltado para o mercado locatício. 0 s prédios e a rua, não por acaso alcunhada de $\mathrm{N}$ ova de São Bento, foram projetados portanto pelos próprios monges beneditinos. A rua tinha 928 palmos de comprimento $(204 \mathrm{~m})$ e 30 palmos de largura $(6,6 \mathrm{~m})$. À exceção dos prédios de esquina que não faziam parte do contrato, todos os outros foram construídos com tipologias idênticas, de acordo com o "risco". Segundo menciona N ireu Cavalcanti, com base nas especificações do contrato, cada unidade apresentava um programa e uma planta-tipo - no pavimento térreo "uma sala, uma camarinha, armazém e varanda", com "as portas que Ihe forem necessárias para os cômodos"; no fundo do quintal, "encostado a o muro, sua cozinha e chaminé e despensa, com um cano para saírem as águas para uma e outra parte da cerca do Mosteiro". Sobre parte do térreo, a partir da sala, levantava-se um sótão, chamado no 
contrato de "sobrado", dividido em sala, dotado de duas janelas abertas sobre a varanda e dois quartos "fechados com portas para a sala". N o fundo de cada prédio deveria ser construído um muro de 15 palmos $(3,3 \mathrm{~m})$ de altura, delimitando os quintais com os terrenos da horta e a sede do mosteiro. Também foram especificados os ma teriais e processos construtivos, nos mínimos detalhes. Longe de sermos anacrônicos, nas devidas proporções, tratava-se de um negócio imobiliário destinado ao mercado locatício, com projeto detalhado, especifica ções técnicas, empreiteiros especia lizados, nos moldes dos modernos empreendimentos dos nossos dias (C AVALC AN TI, 2004, p. 343-344).

$\mathrm{N} 0$ que diz respeito às irmandades laicas, surpreende 0 fato de a 0 rdem Terceira do Carmo e da 0 rdem Terceira de São Francisco disporem apenas de um imóvel cada, em São Paulo, alugados por $3 \$ 840$ rs e $2 \$ 400$ rs a nua is, respectivamente, quando os estudos de Fania Fridman as apontavam entre os mais ricos proprietários do Rio de Janeiro e ativos empreendedores imobiliários.

De qualquer forma, as ordens religiosas - beneditinos, carmelitas e Recolhimento de Santa Teresa - e a Irmandade do Rosário dos Pretos figuravam entre os mais ricos proprietários urbanos de São Paulo em 1809 . As demais Irmandades - das Almas (três prédios $=56 \$ 320 \mathrm{rs}$ ), de Santa Ifigênia (um prédio $=7 \$ 680 \mathrm{rs}$ ), do Rosário dos Brancos (três prédios $=21 \$ 120 \mathrm{rs}$ ), do Santíssimo Sacramento (quatro prédios $=47 \$ 040 \mathrm{rs}$ ), do Senhor Jesus de $\mathrm{N}$ azareth (um prédio $=25 \$ 200 \mathrm{rs}$ ), dos Passos do C armo (um prédio $=8000 \mathrm{rs}$ ), dos Remédios (um prédio $=20 \$ 480 \mathrm{rs}$ ) e do Santíssimo Sacramento da Vila de Santos (um prédio $31 \$ 000 \mathrm{rs}$ ), não chegavam a to talizar montantes muito expressivos, à exceção das Irmandades de São G onçalo (14 prédios $=63 \$ 360$ rs) e de São Pedro (três prédios $=82 \$ 880 \mathrm{rs}$ ).

Entre os leigos institucionais, destacava-se exclusivamente a C âmara, senhora de 10 "cazinhas" na famosa travessa de mesmo nome - especializada no abastecimento da cidade -, a rrematadas por José M endes, cada uma por $24 \$ 000 \mathrm{rs}$, totalizando um montante de $240 \$ 000 \mathrm{rs}$ anuais.

Entre os particulares laicos destacam-se o Coronel Arouche de Toledo e o C oronel Luiz Antonio de Souza - futuro Brigadeiro Luiz Antonio -, sem dúvida, o homem mais rico de São Paulo e uma das maiores fortunas da Colônia no período (ARAÚJO, 2003).

$\mathrm{N}$ a análise dos dados fornecidos no Livro da Décima Urbana sobressa em algumas curiosidades como a de que o engenheiro-militar João da Costa Ferreira possuía dois valorizadíssimos imóveis, um sobrado de dois lanços e um andar na Rua de São G onçalo, n. 34 (atrás da Sé, alugado por 38\$400 rs a nuais) e uma "logea" na Travessa das Casinhas, n. 3, alugada a $24 \$ 000 \mathrm{rs}$ anuais. Ta mbém o célebre mestre pedreiro Joaquim Thebas era possuidor de um imóvel, situado à Rua do Rego, n. 40 (próxima à Ponte do Lorena), que por estar em obras o obrigava a residir de aluguel na casa térrea vizinha, pagando $9 \$ 600$ rs anuais.

0 utra curiosidade é que o Bispo Diocesano (M ateus de Abreu Pereira) habitava num sobrado de dois lanços e um andar - o mais caro de São Paulo, 
situado na Rua do Carmo, n. 49 -, pagando $102 \$ 400$ rs de aluguel anual a 0 testamenteiro de $D$. Francisca $M$ aria de $M$ attos. $N$ ão contente com isso, alugava também idêntico sobrado vizinho, n. 48 , pertencente ao Convento do Carmo, pagando mais $40 \$ 000$ rs anuais. Sabemos que também era proprietário da C hácara da G lória, correspondente aos a tua is bairros Vila Deodoro e Cambuci. É interessante anotar que os homens mais ricos da cidade, em geral, possuíam chácaras no perímetro urbano, que nessa altura englobava o antigo "rossio", tal como nos mostra a Planta da Cidade de São Paulo, levantada em 1810 , pelo engenheiro Rufino José Felizardo e Costa (Figura 8). Esse é o caso do Coronel Luiz Antonio de Souza - proprietário de uma chácara junto da Rua da Consolação (esquina com a atual Avenida S. Luís) - , do Coronel Francisco Xavier dos Santos - vizinho do anterior -, de D. M arianna Fortes, do Coronel A rouche e do Coronel G avião (futuro Brigadeiro Bernardo José Pinto $G$ a viã o Peixoto, pai do Capitão José M aria G avião Peixo to). Todos parecem desfrutar das suas chácaras por puro conforto, como uma espécie de segunda residência, na medida em que acreditamos ainda não se tratar de um investimento para especulação imobiliária, como o será mais tarde.
6. Rossio = área envoltória às vilas pertencente à Câmara Municipal. Patrimônio público, administrado pelas Câmaras, destinava-se à pastagem de animais, coleta de madeira e lenha, expansão da cidade e obtenção de renda com a concessão de terras.Cf.MARX,1991.

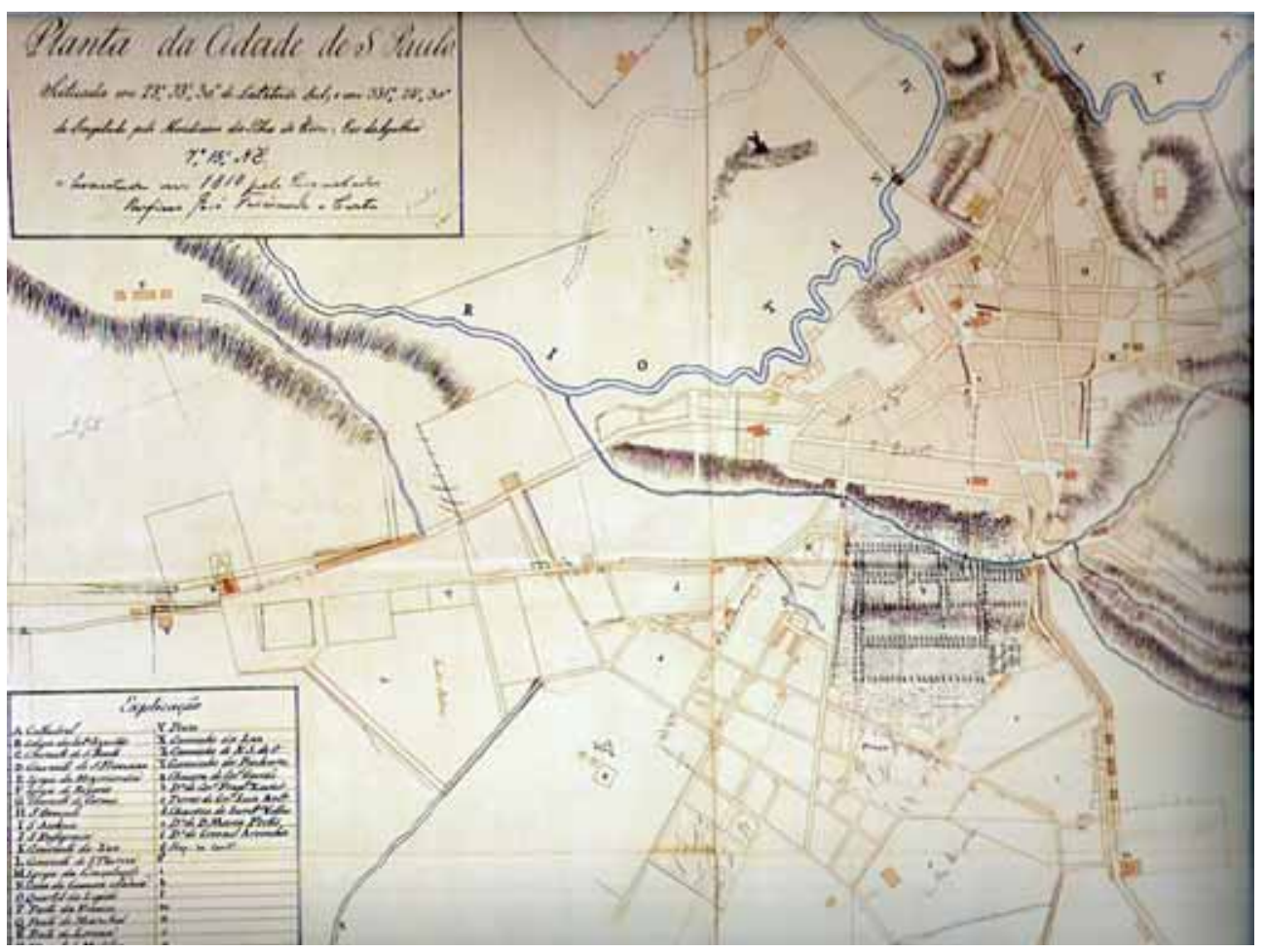

Figura 8 - Planta da Cidade de S. Paulo [...] levantada em 1810 pelo Engenheiro Rufino José Felisardo e Costa". C oleção M useu Paulista - USP. 0 bservar as chácaras existentes na então Freguesia de S. Ifigênia: a) Chácara do G avião; b) C hácara do Dr. Francisco Xavier (depois legada a o primo, o Barão de Itapetininga); c) Terras do Coronel Luiz Antônio de Souza; d) C hácara do Secretário Velho; e) C hácara de D. M arianna Fortes; f) C hácara do Coronel Arouche. 
$\mathrm{N} 0$ entanto, em geral, a maioria desses mesmos personagens dispõe também de moradias no perímetro urbano. A Décima de 1809 nos fornece os endereços residencia is urbanos de a lguns deles. Por exemplo, o C oronel-Inspector Jozé A rouche de Toledo possuía um sobrado residencial na $R$. de São Bento, $n$. 21 (de dois lanços e um andar) e D. M arianna Fortes possuía um sobrado (de do is lanços e um andar) na Rua de Trás da Sé, n. 6. Já o Coronel Luiz Antonio parece residir na chácara, pois no local do seu futuro sobrado (esquina das Ruas do O uvidor e São Bento) possuía apenas uma "loja e um lanço", onde estabelecera a "Casa Souza", e seus outros seis imóveis estavam alugados.

À exceção de D. Ursula M aria Luiza das Virgens (tia de Francisco de Paula Xavier de Toledo) que morava na Travessa do Colégio, n. 10, num sobrado de um andar exclusivamente residencial, os outros grandes detentores de patrimônio imobiliário na cidade de São Paulo, em 1809 , apresentavam endereços que atestavam suas atividades predominantes. Jozé Antonio da Silva Paulista residia na Rua do Rosário, n. 46, num sobrado de uma loja e dois lanços; o C a pitão M a nuel da Luz Tra lhão, na Rua do 0 uvidor n. 6, num sobra do de uma loja e um andar; o Coronel Joze Vaz de Carvalho, na Rua Direita n. 31 , num sobrado de uma loja e um andar; o Dr. Antonio Soares Calheiros, no Largo do Bexiga n. 1, num sobrado de uma loja e um andar; D. Josefa M aria do Espirito Santo, na Rua do Comércio n. 1, num sobrado de duas lojas e um andar; Joa quim Jozé da Silva, na Rua do Rosário n. 13, num sobrado de cinco lojas e um andar; o Capitão João Lopes França, na Rua do Rosário n. 59, num sobra do de uma loja e um andar; o C apitão G abriel Jozé Roiz, no Largo da Sé n. 4, num sobrado de uma loja e um andar; $D$. Anna de Almeida, na Rua do Comércio n. 25, num sobrado de cinco lojas e um andar (quatro alugadas e quiçá uma, mais o andar, de uso próprio). A localização e tipologia dessas residências de uso misto, é indicativa das suas atividades como importantes negociantes e comerciantes da cidade.

Ao contrário do que afirma Raquel Rolnik (2003, p. 102), a propriedade imobiliária não era irrelevante do ponto de vista da composição da riqueza. O s estudos de Zélia Cardoso de Mello (1985) e M aria Lucília Viveiros de Araújo (2003) - para o caso de São Paulo - e de Fania Fridman (1999), João Luís Fragoso (1998) e N ireu Cavalcanti (2004) - para o caso do Rio de Ja neiro - desmentem tais considera ções feitas sem base empírica, calcadas, em exemplos genéricos:

A propriedade imobiliária até a década de 1870 era muito pouco relevante do ponto de vista da composição da riqueza. Lembremo-nos que quando 0 barão de Iguape faleceu, em 1875, sua neta Ana Brandina da Silva Prado, casada com Antonio Pereira Pinto Jr. a contragosto da família, foi deserdada e recebeu como herança a casa do avô, velho sobrado de taipa situado nos $Q$ uatro $C$ antos, isto é, na rua de São Bento, esquina com a rua Direita, um dos vértices do Triângulo. Sua irmã A nésia, neta predileta, foi contemplada com uma cômoda!.

Um inventário de 1868 também demonstra a insignificância das propriedades 
imobiliárias em relação a outras formas de riqueza: 10 mil metros quadrados de terreno perto da cidade (atual rua dos Guaianazes) - $100 \$ 000$ réis; um sobrado de taipa de pilão na rua Boa Vista, no coração da cidade $1000 \$ 000$ réis, Chácara Pacaembú (incluindo os atua is ba irros de Perdizes, Pacaembú e parte da Barra Funda, Lapa e Várzea do Tietê) - $2400 \$ 000$ réis; escravos que iam de $M$ aria, 60 anos, $40 \$ 000$ réis, a Faustino, 35 a nos, mulato, alfaiate, $600 \$ 000$ réis; piano $100 \$ 000$ réis; bacia de cobre $60 \$ 800$, etc. Um piano valia tanto quanto um terreno de 10 mil metros nos a rredores da cidade; um escravo jovem e com ofícios valia quase tanto como um grande sobrado no centro da cidade.

Como vimos no capítulo 1 , essa situação se alterou no final do século, resultado sobretudo do deslocamento do capital imobilizado no escravo para a terra e da possibilidade aberta pelos estabelecimentos bancários de lastrear empréstimos para lavoura e outros negócios a través de hipotecas. Era possível ta mbém levantar outras hipóteses de constituição de um mercado imobiliário na cidade: por um lado, a quebra do Banco M a uá, uma das mais sólidas casas bancárias do Império, teria gerado receio entre os capitalistas de guardar dinheiro em estabelecimentos bancários. Por outro lado, Raffard apontava a espetacular conversão de imóveis urbanos em investimentos a ltamente valorizados dos fazendeiros, antes empregados na construção de ferrovias [...]. 0 s fazendeiros também temiam a depreciação de suas propriedades a grícolas ou qua isquer outros títulos, em conseqüência da abolição da escravatura e da proclamação da República. De qualquer forma, o crescimento demográfico, a imigração e a presença na cidade de conting entes cada vez maiores de assala riados, artesãos e comerciantes, a liada à disponibilidade de capita is para investimentos, to rna vam o mercado de imóveis não só possível como altamente rentável (RO LN IK, 2003, p. 102).

C ertamente o fenômeno assume outras proporções após a abolição da escravidão e a Proclamação da República, mas não era inexistente no período anterior. A sua natureza é que muda - de "rentista" à "capitalista" - , bem como sua área de abrangência - produzindo a primeira expansão urbana além rios Tamanduateí e Anhangabaú.

N o que diz respeito ao período 1809 a 1870, o estudo de Maria Lucília Viveiros Araújo (2003) dos inventários post-mortem dos membros das famílias mais ricas da cidade de São Paulo nos permite aferir o peso da propriedade imobiliária (rural e urbana) nas suas fortunas:

- Coronel - futuro Brigadeiro - Luiz Antonio de Souza (negociante e fazendeiro português) $=12 \%$ imóveis rurais e urbanos; $39 \%$ bens profissionais; $29 \%$ dívidas ativas; $12 \%$ escravos (613).

- Coronel Francisco Pinto Ferraz (negociante e fazendeiro português), casado com Ana Francisca N ovaes de Magalhães $=23 \%$ imóveis 
rura is e urbanos; $63 \%$ dívidas ativas (empréstimo de dinheiro a juros); $2 \%$ escravos.

- Francisco Inácio de Souza (português, sobrinho e genro do Briga deiro Luís A ntônio; neg ociante e fa zend eiro) $=40 \%$ imóveis rura is e urba nos $(26) ; 39 \%$ escravos (229); $5 \%$ a nima is.

- Coronel - futuro Brigadeiro - M anoel Rodrigues Jordão (negociante e fazendeiro) $=17 \%$ imóveis rurais e urbanos $(17) ; 28 \%$ escravos (281); $27 \%$ dívidas a tivas.

- Coronel Joa quim José dos Santos (negocia nte de escravos, fazendeiro e pai do Barão de Itapetininga) $=53 \%$ imóveis rurais e urbanos (12 imóveis, dentre os quais 10 casas na capital); $35 \%$ escravos (8 7 escravos $=32$ urbanos e 45 rurais).

- Dr. Rodrigo Antônio M onteiro de Barros (0 uvidor e Desembargador, mineiro; negociante e fazendeiro $=15 \%$ imóveis rura is e urbanos; $43 \%$ dívidas a tivas; $23 \%$ rendas diversas; $10 \%$ escravos.

- Coronel Anastácio de Freitas Trancoso (negociante e fazendeiro) = $61 \%$ imóveis; $6 \%$ bens profissiona is; $17 \%$ escravos (26); 7 \% a nima is.

- Marechal de Campo M anoel de 0 liveira Cardoso (negociante de fazendas secas) $=59 \%$ bens imóveis; $34 \%$ dívidas a tivas.

- José Pinto Tavares (negociante português) = 18 propriedades (7 casas na capital).

- C a pitão M anoel da Luz Tralhão (negociante; pardo, solteiro e natural de C uiabá) = $35 \%$ (15 propriedades urbanas; maior quantidade de casas alugadas na cidade); $2 \%$ escravos (5).

À exceção dos três últimos, os demais eram todos negociantes e fazendeiros. Ao grupo somava-se José Vaz de Carvalho, sogro do Dr. Francisco José de Sampaio Peixoto, que encabeçava junto do genro o négocio de muares, sendo a rrematante do contra to de Curitiba entre 1799 e 1805.

São, portanto, homens cuja fortuna advém sobretudo de atividades urbanas - negócios, comércio, empréstimo de dinheiro a juros e renda de aluguel.

o s estudos realizados para o caso do Rio de Janeiro, por Fragoso e Cavalcanti, a menos no que diz respeito aos homens essencialmente urbanos (os ricos comerciantes de "grosso trato", voltados para o comércio internacional), a pontam que tais fortunas se ancoravam em grande parte no patrimônio imobiliá rio "rentista" urbano.

C om base nos inventá rios post-mortem, Zélia C a rdoso de M ello (1985, p. 126 ) caracterizou o perfil empresarial de alguns dos ricos proprietários de imóveis urbanos integrantes da lista dos 20 mais ricos de São Paulo. Por exemplo, - Capitão João Lopes França possuía além de casas de aluguel em São Paulo, uma chácara, um sítio na Freguesia do Juqueri, 15 escravos e uma sociedade 
com negócio de açúcar, bestas e escravos. Seus rendimentos provinham dos aluguéis, empréstimos e negócios realizados. Também o futuro Barão de Itapetininga (1877), homônimo e filho do Coronel Joaquim Jozé dos Santos (negociante de escravos), figura va entre os "empresários" paulistas ma is prósperos da segunda metade do 0 itocentos. Embora não apresentasse fortuna de origem propriamente a grária, possuía valorizados bens dessa natureza. A notado em to dos os almanaques do período como "proprietário e capitalista", fazia jus à qualifica ção, chegando a possuir 32 casas de aluguel em São Paulo, terrenos e cháca ras. A lém disso fo i prop rietá rio de três fazendas, somando 2.000 a lqueires com 398.000 pés de café, casa de máquinas, engenho e mais de 200 escravos. Suas receitas provinham de aluguéis, café e empréstimo de dinheiro a juros. Entre os bens recebidos por herança relacionam-se 14 casas em São Paulo, "terras no C há" (herdadas do primo Francisco Xavier dos Santos) e escravos.

Por sua vez, o Livro da Décima nos traz informações curiosas sobre um certo Dr. Antonio Soares Calheiros, dono do Largo do Bexiga, já que detentor das 12 casas que o compunham, residindo no n. 1, num sobrado de uma loja e um lanço. Possuía um patrimônio de 24 casas, ocupando a 11 à posição na lista dos 20 maiores proprietários de imóveis urbanos.

Sobre o Tenente-C oronel Anastácio de Freitas Trancozo, segundo dados fornecidos pelo Livro da Décima, possuía um patrimônio de oito casas, sete delas alugadas, situadas nas ruas do Comércio (um), São G onçalo (duas), Travessa de Santa Tereza (três) e Rua do Príncipe (duas), totalizando um montante de $102 \$ 880 \mathrm{rs}$. Residia na Rua de S. Teresa, num sobrado de dois lanços. Pai de Francisco Pinto do Rego, combinava atividades comerciais à produção a grícola. Seu sítio na Freguesia do ó, às margens do Rio Tietê, deu origem, mais tarde, a o bairro de Vila Anastácio. Tinha três filhas solteiras que residiam reclusas na Rua do Carmo (M ARIN S, 1999, p. 221 ), mantidas pelos cabeda is do pai.

Em relação às mulheres, as mais ricas em imóveis de renda parecem ser, em geral, as solteiras. A lém das filhas do Tenente-C oronel Anastácio, nos referimos às irmãs Toledo Rendon e $D$. M arianna Angélica Fortes Bustamante Sá Leme. Esta última ganhou luz nos trabalhos de Paulo G arcez M arins (1999, p. 236; 2002 ), não só como a rica trineta de Fernão Dias Paes, irmã de D. Anna Leoniza de Abilho Fortes, mas sobretudo pelo grande infortúnio sofrido pelo fa to de ter tido um filho natural bastardo do Governador da Capitania Bernardo José de Lorena, chegando a receber um "patético a testado da Câmara" ressaltando que, junto da irmã, residia "recolhida" em sua casa "com muita distincção e lei de nobreza". Rica porém celibatária, D. M arianna Fortes possuía a lém das 11 casas de aluguel, uma chácara junto da Rua de Santa Ifigênia.

Entre os comerciantes, embora não figurando na lista dos 20 mais, destacava-se também o lisboeta Joaquim Jozé de 0 liveira, residente na Rua Direita, n. 3, num sobrado de uma loja e um andar, no valor de $38 \$ 400$ rs. Possuía um patrimônio de seis imóveis urbanos (totalizando $72 \$ 960 \mathrm{rs}$ ), seqüestrados em 1810 pela Junta da Cruzada da Corte do Rio de Janeiro (M ARIN S, 1999, p. 
218), dado que suas dívidas excediam seu patrimônio no momento do seu inventário.

Q uanto ao Coronel Luiz Antonio de Souza, futuro Brigadeiro Luiz Antonio, destacava-se como ilustre fazendeiro no oeste paulista, com múltiplas atividades urbanas. Chefe do prestigioso clã dos Souza $Q$ ueiroz, seus filhos notabilizaram-se como os futuros Barões de Limeira e de Souza Q ueiroz. Era casado com D. G enebra de Barros Leite, irmã do 1 - Barão de Piracicaba, Antonio Pais de Barros. Detinha cinco imóveis só na Rua do 0 uvidor e, embora o de n. 34 correspondesse ao local do seu futuro sobrado (na esquina com a Rua de S. Bento), em 1809, não passava de uma loja e um lanço, destinada ao comércio - "Casa Souza". Como já dissemos, nessa época provavelmente a família residisse na chácara.

Também os famosos sobrados do Barão de lguape e do Brigadeiro Jordão, situados nos $Q$ uatro $C$ antos, famosa esquina das Ruas Direita e $S$. Bento, ainda não haviam sido construídos em 1809 . N em mesmo Antônio da Silva Prado figurava entre os proprietários de imóveis urbanos em São Paulo nesse período, talvez residindo em Jundiaí, envolvido com o comércio do açúcar, escravos e algodão, estabelecendo-se em São Paulo apenas a partir de 1816 (BRITO , 2000, p. 77-78). Entre os membros dessa prestigiosa família, destacase, em 1809, a penas um dos filhos do Capitão-M or M artinho da Silva Prado, o C a pitão Eleutério da Silva Prado, negociante, residente na Rua de S. Bento n. 22, num sobrado de dois lanços e um andar, e dispondo de dois imóveis que totalizavam $22 \$ 080$ rs.

Dos membros da futura elite paulistana do século XIX, figuram no Livro da Décima apenas os nomes de Jaime da Silva Telles, proprietário de qua tro casas, mas residente num sobrado alugado, pertencente à Irmandade de São Pedro, no Largo da Sé $n$. 2 . Além dele, destaca-se 0 nome do $C$ oronel $M$ anuel Rodriguez Jordão - futuro Brigadeiro Jordão e pai do Barão do Rio Claro - a inda não residente no famoso sobrado dos $Q$ ua tro $C$ antos da Rua Direita com $S$. Bento, mas quiçá no seu único imóvel, um sobrado de duas lojas e um andar, sito à Rua de S. Bento, n. 13, avaliado em $24 \$ 000$ rs. Ta mbém o Dr. N icolau Pereira de Campos Vergueiro a parece timidamente como possuidor de um único imóvel, sua provável residência, situada na Rua Direita e avaliada em $30 \$ 720$ rs. 0 C oronel Francisco Xavier dos Santos a parece como proprietário de seis casas, quatro na Rua de São José (n. 7, 38, 39 e 40) e duas na Rua Direita (n. 26 e 27 ), totalizando um patrimônio de $92 \$ 160 \mathrm{rs}$, além de figurar na planta da cidade de 1810 como o proprietário da chácara do "C há".

Convém a presentar uma breve comparação com o caso do Rio de Janeiro, no mesmo período. Segundo Fania (FRIDMAN, 1999, p. 47), os beneditinos, entre 1651 e 1750 , chegaram a ser proprietários de 37 terrenos e 48 casas de aluguel. Com recursos provenientes dos aluguéis e do gado, a área em torno ao mosteiro foi loteada, sacrificando parte de sua horta. Sua atuação urbana foi ampliada (FRIDM AN , 1999, p. 63-64) e somente no período entre 1743 e 1775 foram erigidas 29 casas na "Rua N ova de São Bento", como vimos aberta para tanto. De 1751 a 1850 , a 0 rdem acumulou mais de 
203 casas de aluguel e 29 terrenos foreiros (FRIDM AN, 1999, p. 71 ). N 0 período colonial, na capital do Brasil, os foros e aluguéis recebidos pelas propriedades no núcleo central da cidade chegavam a superar a renda proveniente dos engenhos, fazendas, denotando o surgimento de uma atividade urbana - a imobiliária - sobretudo nas áreas nobres.

Tal como em São Paulo, embora monopolizassem boa parte do tecido urba no da cidade, as ordens religiosas e irmandades não chegaram a ultrapassar, em número, o montante do patrimônio imobiliário la ico - sobretudo concentrado nas mãos de homens urbanos, ricos negociantes de "grosso tra to" vinculados a o comércio internacional ou negociantes ligados a comércio regional e local. De longe, no conjunto, os leigos foram os maiores agentes produto res do espaço urbano carioca, a o menos em princípios do século XIX, e outros menos importantes, mas igualmente negociantes e comerciantes, os produtores e detentores de boa parte do tecido urbano de São Paulo. Portanto, embora individualmente as ordens religiosas e irmandades laicas (no caso do Rio de Janeiro) imperassem como os maiores investidores em imóveis urbanos no perío do colonial, não chegavam a sobrepor os particulares nas somas de conjunto.

Implementada por meio do Alvará de 27/6/ 1808, a Décima Urbana incidiu também nos imóveis da Corte sobre as Freguesias da Sé, Candelária, Santa Rita, parcialmente São José (no trecho que se estendia pelo bairro da G lória e do Catete, indo a té a atual Praça José de Alencar, penetrando pelo ca minho de La ranjeiras, em direçã o às Paineiras). Ta mbém incluiu pequeno trecho do Engenho Velho, correspondente a o caminho de Mataporcos (atual bairro do Estácio), terminando às margens do Rio Comprido. Esse vasto perímetro urbano foi divido em dois setores - Sé, São José, Engenho Velho; Candelária e Santa Rita - , sendo a área da Freguesia da C andelária a com maior taxa de ocupação e de verticalização. Ao contrário de São Paulo, em que todos os imóveis foram registrados num único livro, a tributação da Décima no caso do Rio de Janeiro resulto u em vários volumes. 0 primeiro aberto em 4/ $1 / 1809$ (Sé, São José e Engenho Velho) e o terceiro aberto em 12/ 7/ 1810, compreendendo as outras freguesias. Entre 1808 e 1810 foram cadastrados 146 logradouros (C AVALC AN TI, 2004, p. 259-263), 46,6\% catalogados como ruas.

As tipologias das edificações variavam entre casas térreas, sobradinhos, sobrados de um, dois ou três andares (com ou sem lojas no térreo). Além dos pavimentos, outros complementos como sótãos e trapeiras também foram registrados. Além das casas, observa-se um maior detalhamento quanto a os outros tipos de imóveis e seus usos: casa de vivenda, loja, sobreloja, armazém, açougue, trapiche, cocheira, senzala, telheiro, casa de banho, pardieiro, corredor, quartos, rótulas, casas com hortas ou quintal, chácaras e terrenos ("chãos", "terreno devoluto" ou simplesmente "terreno") (C AVALCAN TI, 2004, p. 264 ), diferentemente do caso paulista, menos detalhado nesse sentido.

Tal como em São Paulo, foi estabelecida pela primeira vez uma numera ção. C ritérios subjetivos orientaram os pontos de partida da numeração, o que hoje dificulta muito o mapeamento dos dados.

N o Rio de Janeiro, dos 7.548 imóveis a rrolados, mais da metade, 
4.878, correspondia a edificações de um único pavimento. A capital do Brasil ta mbém era uma cidade predominantemente de prédios baixos; $65 \%$ horizontal. As edificações térreas predomina vam nas extremidades (Engenho Velho, Sé, Santa Rita e São José). A área verticalizada e mais a densada esta va concentrada na Freguesia da Candelária, totalizando um conjunto de 858 sobrados, que predominavam sobretudo nas ruas ma is importantes, nas proximidades do La rgo do Paço, da zona comercial e portuária, no trecho entre a Ponta do Calabouço e o Arsenal da Marinha. A Freguesia da Candelária também abrigava os logradouros e prédios mais importantes - grandes estabelecimentos comerciais dos a tacadistas exportadores e importadores. Segundo N ireu (C AVA LC AN TI, 2004 , p. 267 ), com base no Almanaque de 1794, dos 127 negociantes mais importantes da cidade, 114 tinham seu comércio na Candelária; 67 deles (59\%) instalados só na Rua Direita, a principal da cidade. 0 s imóveis registrados exclusivamente para cocheiras ou de uso misto para tanto - residencial ou comercial - eram pouquíssimos, só 52 . Possuir uma cocheira era indicativo de "status" social e somente os comerciantes de "grosso tra to" as possuíam em área urbana valorizada; eram os estacionamentos da época.

0 s prédios nã o-residenciais era m poucos: oito trapiches, 40 armazéns, duas lojas e 26 telheiros, num total de 76 edificações. N umerosíssimos eram os imóveis de uso misto, 1.456 com lojas e 16 com armazéns. 0 Almanaque de 1799 a testa a existência de 1.311 lojas de varejo ou oficinas, quantia muito próxima das 1.456 edificações citadas pela Décima. Segundo N ireu, o número reduzido de prédios de uso exclusivamente comercial seria uma conseqüência da não especialização dos espaços urbanos, algo também observá vel em São Paulo (C AVALC AN TI, 2004 , p. 271 ). Foram registrados 26 terrenos - sete deles "devolutos" - , a o passo que em São Paulo, apenas um. A vinda da Corte, induziu o parcelamento das chácaras e uma crescente especulação imobiliária nos arrabaldes da cidade; em São Paulo tal fenômeno é a penas observado a partir de meados do século, intensificando-se com a chegada dos imigrantes.

$Q$ uanto ao perfil dos proprietários, $N$ ireu contabilizou 2.668 nomes para 7.548 imóveis. Em São Paulo eram 748 nomes para 1.281 imóveis. Do to tal registrado na Corte, $86,6 \%$ pertenciam a pessoas físicas (aí incluídos os padres seculares), $0,4 \%$ à Fazenda Real e $12,7 \%$ a instituições predominantemente religiosas (a o passo que em São Paulo $81,64 \%$ estavam concentrados nas mãos de leigos - 10 imóveis só nas mãos da Câmara - e $18,27 \%$ nas mãos das 0 rdens Religiosas, Irmandades e Padres Secula res). Para o autor, nas somas de conjunto, pouco expressivo era o patrimônio imobiliário concentrado nas mãos das 550 rdens Religiosas, Irmandades ou C onfrarias (Santa Casa de M isericórdia aí inclusa). Pela Décima (1809-1812) verifica-se que esses 55 proprietários instituciona is de cunho religioso possuíam 956 imóveis, a saber: 0 rdem Terceira de São Francisco da Penitência (186); M osteiro de São Bento (163); Convento do Carmo (125); Santa Casa de M isericórdia (104) (C AVALC AN TI, 2004 , p. $272-273$ ). N o caso de São Paulo a ordem era: M osteiro de São Bento (61), Convento do Carmo (22), Recolhimento de Santa Tereza (15) e Irmandade do Rosário dos Pretos (9). Como já dissemos, individualmente, 
destacavam-se as ordens religiosas e irmandades; no conjunto destacavam-se os leigos.

Dos 7.549 imóveis a rrolados, 6.535 estavam nas mãos de 2.585 proprietários particulares. N ota-se uma forte concentraçã o, estando $61,1 \%$ de posse de um único imóvel; 17,8\% de dois imóveis e 7,6\% (ou seja 197 indivíduos) com cinco ou mais imóveis. Maioria esmagadora pertencia a o sexo masculino; 145 eram religiosos (senhores de 273 imóveis) e quatro religiosas (com 12 imóveis). Um conjunto de 89 proprietários (3,4\% dos individuais) concentra va $20,7 \%$ do total dos imóveis urbanos e deles auferia a vultosa receita anual de $131.863 \$ 873$ rs, equivalente a 42,2\% da receita da Alfândega da Capitania do Rio de Janeiro, que em 1806 arrecadara $312632 \$ 430$ rs. Destes, 34 eram negociantes a tacadistas. Dos 36 negociantes listados como os mais expressivos nos Almanaques de 1799 e 1811 , dez faziam parte da lista dos 89 maiores proprietários de imóveis urbanos do Rio de Janeiro (C AVALCAN TI, $2004, p$. 274 ). A mesma concentração nas mãos de poucos, muitos deles negociantes, foi observada em São Paulo.

Isso a testa que investimentos no setor imobiliá rio eram considerados promissores e seguros. A receita sob forma de aluguéis foi a opção de investimento adotada por ricos comerciantes cariocas, ta is como os herdeiros de José $C$ aetano de Araújo (41 prédios $=8.267 \$ 035 \mathrm{rs}$ ); C leto M arcelino Ferreira (22 prédios = $5.962 \$ 476 \mathrm{rs}) ;$ os herdeiros de Antonio Leite $(54$ prédios $=4.891 \$ 006 \mathrm{rs})$; $\mathrm{M}$ anoel Alvares da Fonseca Costa (62 prédios $=4.060 \$ 800 \mathrm{rs}$ ); José Francisco do Amaral (4 8 prédios $=3.728 \$ 160$ rs); José da Costa Araújo Barros (22 prédios $=3.016 \$ 993 \mathrm{rs}$ ); Domingos Francisco de Araújo Rozo (31 prédios = $2.772 \$ 920 \mathrm{rs}$ ); Antonio José Ribeiro G uimarães (nove prédios $=2.638 \$ 240 \mathrm{rs}$ ); Brás C arneiro Leão (oito prédios $=2.590 \$ 400$ rs); a viúva Francisca M aria da Conceição (52 prédios $=2.501 \$ 760 \mathrm{rs}$ ); Bernardo Francisco de Brito (20 prédios $=2.365 \$ 052 \mathrm{rs}$ ); a viúva Maria Luiza de Souza Dias (nove prédios = $2.318 \$ 840 \mathrm{rs}) ;$ Francisco Xavier Pires (20 prédios $=2.302 \$ 200 \mathrm{rs}$ ); M a noel C a etano Pinto (32 prédios $=2.116 \$ 542 \mathrm{rs}$ ) e por fim José Rodrigues de C arvalho (19 prédios $=2.062 \$ 200 \mathrm{rs}$ ). $0 \mathrm{~s}$ montantes dos maiores proprietários paulistas são ínfimos quando comparados aos da Corte; os imóveis e os aluguéis valiam bem mais no Rio de Janeiro; certamente pelo fato de se tratar da Capital do Brasil, com solo urba no mais valorizado, além de dispor de edificações em pedra e cal, mais altas e maiores em área útil.

0 bservam-se 221 edificações em construção, ao passo que em São Paulo se registraram 41 em obras; a lgo considerá vel, se compararmos a dinâmica e a demanda (chegada da Família Real e comitiva) entre cidades tão diversas. Dos fogos da Candelária, $86 \%$ eram ocupados por inquilinos, significando que o imóvel para aluguel se tornava mais atraente e lucrativo à medida que se aproximava da zona central, do comércio, dos grandes negócios, etc. $\mathrm{N}$ ireu calculou que a rentabilidade média era de $6,8 \%$; portanto, mais elevada que os $5 \%$ permitidos por lei se a mesma quantia em dinheiro fosse emprestada a juros. $\mathrm{N} 0$ Livro n. 144 do 200 fício de $\mathrm{N}$ otas - pertencente a o Arquivo $\mathrm{N}$ acional -, no período entre 1807 e 1809,76 escrituras referentes a transações imobiliárias 
de imóveis urbanos foram localizadas por $\mathrm{N}$ ireu $\mathrm{C}$ avalcanti, correspondendo a negócios envolvendo 43 prédios térreos, 19 sobrados, cinco chácaras e nove terrenos, movimentando um montante de $95608 \$ 000 \mathrm{rs}$ - cifra cinco vezes maior que 0 valor obtido com as exportações da Capitania do Rio de Janeiro no mesmo perío do (C AVALCAN TI, 2004 , p. 278-280).

Pesquisa semelhante precisa ser realizada para o caso de São Paulo, com intuito de avaliar comparativamente a dinâmica do seu mercado imobiliário. De qualquer forma é possível a firmar que em fins do período colonial era bom negócio empatar capital em casa de aluguel - 1,8\% mais rentável que emprestar dinheiro a juro, sobretudo resultando em bem menos riscos. Aspecto pouco contemplado pela historiografia nos seus estudos sobre a cidade colonial brasileira, procuramos enfatizar que boa parte do tecido urbano das cidades brasileiras, desde as suas origens, foi um produto socialmente construído, fruto da inicia tiva privada, sendo o so lo urba no e o casa rio passíveis de mercantiliza ção desde tempos muito remotos.

Finalizando, apresentamos a prancha com a reconstituição do tecido urbano e cenário do Largo da Sé, de acordo com os dados cadastrados no Livro da Décima, confrontados com as fichas do Fundo Aguirra e a iconografia disponível, incluindo o nome dos proprietários dos imóveis. Trata-se de uma amostragem de um trabalho que envolveu também a reconstituição das ruas Direita, S. Bento, 0 uvidor, C omércio, Rosário, Santa Tereza, Carmo e dos largos do Palácio e de S. G onçalo. É interessante observar que o cenário ganhou vida a o descortinarmos, por detrás das fachadas, os a tores socia is envolvidos na produção daqueles espaços (Figura 9 ). 


\section{Largo da Sé}

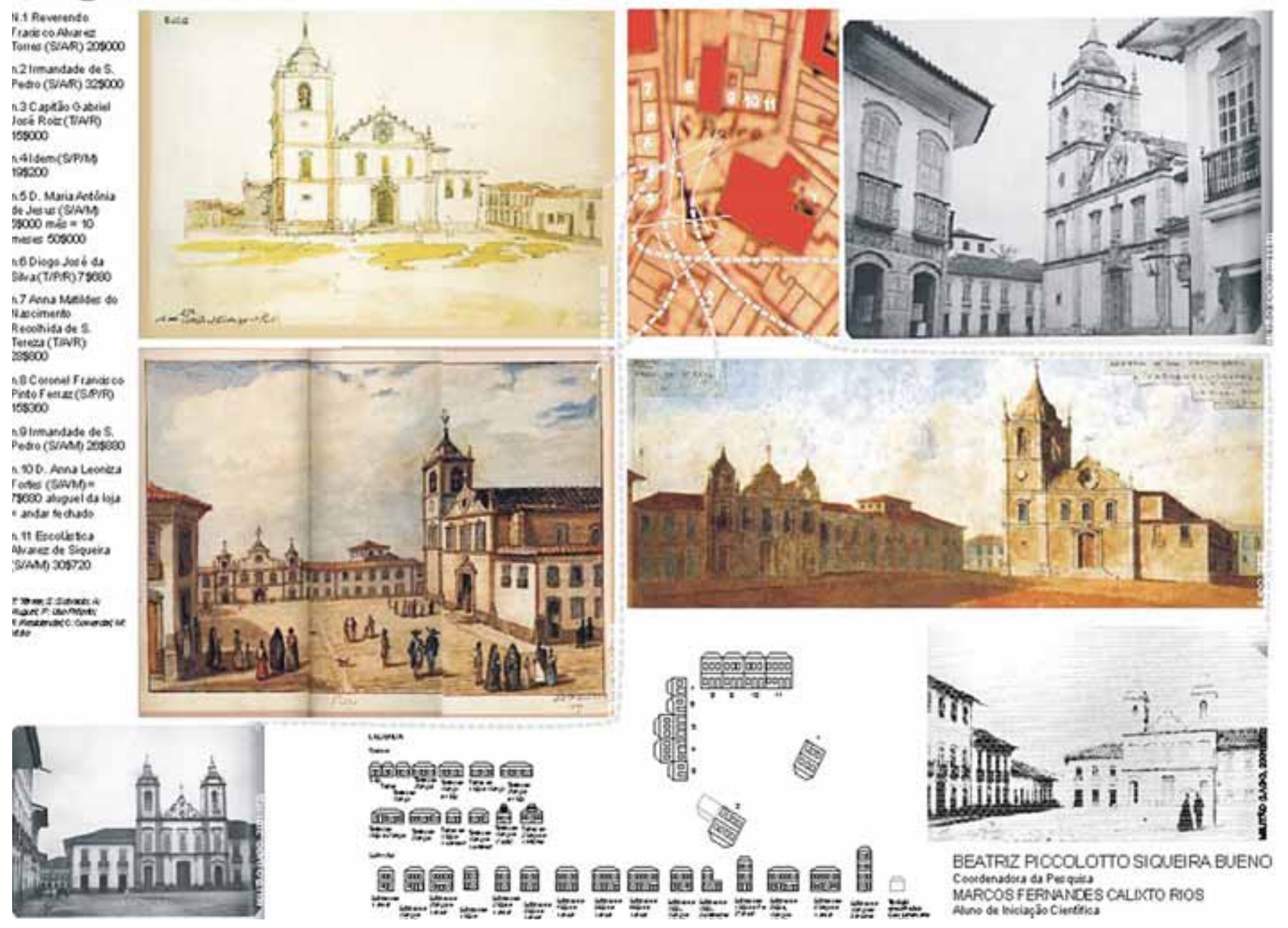

Figura 9 - Largo da Sé. Autora da Prancha: Beatriz P. Siqueira Bueno. As imagens dos viajantes foram reproduzidas de LAG 0 , 2003, p. 37, 69, 92-93. O s desenhos origina is pertencem: "C a thedral Kirche zu St. Paul", Thomas Ender, 1817, Kupferstichkabinett der A kademie der bildenden Künste, Viena; "C athedral Square, St Pauls", 1823, Edmund Pink, Acervo de Artes da BO VESPA, São Paulo; "S. Pedro", 1827, J. B. Debret, Coleção Beatriz e Mário Pimenta Camargo, São Paulo. As fotografias de M ilitão Augusto de Azevedo pertencem ao Museu Paulista da USP. 


\section{REFERÊN CIAS}

ARAÚjO, M. L.V. Os caminhos da riqueza dos paulistanos na primeira metade do Oitocentos. Tese (D outorado) - Departamento de História da Faculdade de Filosofia, Letras e Ciências Humanas da Universidade de São Paulo, 2003.

BARBUY, H. M. S. A cidadeexposição: comércio e cosmopolitismo em São Paulo, 1860-1914 (Estudo de História e Cultura Material).Tese (Doutorado) - Faculdade deArquitetura e Urbanismo, Universidade de São Paulo, 2001.

BRITO, M. S. A participação da iniciativa privada na produção do espaço urbano: São Paulo, 1890-1911. Dissertação (Mestrado) - Departamento de Geografia - FFLCH/USP, 2000.

CAMPOS, E. Arquitetura paulistana sob o Império. Aspectos da formação da cultura burguesa em São Paulo.Tese (Doutorado) - FAU/USP, 1997.

CAMPOS NETO, C. M. Os rumos da cidade. Urbanismo e modernização em São Paulo. São Paulo: Editora Senac, 2002.

CAVALCANTI, N. O Rio de Janeiro Setecentista.A vida e a construção da cidade da invasão francesa até a chegada da Corte. Rio de Janeiro: Zahar, 2004.

COLLECÇÃO DAS LEIS DO IMPÉRIO DO BRASIL,T. 11, Parte 1ạ , Secção 44ạa, 1850.

DIAS, M. O. L. da S. Quotidiano e poder em São Paulo no século XIX. São Paulo: Basiliense, 1984.

FRAGOSO, J. L. Homens de grossa aventura.Acumulação e hierarquia na praça mercantil do Rio de Janeiro (1790-1830). 2ª ed. Rio de Janeiro: Civilização Brasileira, 1998.

FRIDMAN, F. Donos do Rio em nome do Rei. Uma história fundiária da cidade do Rio de Janeiro. 2a ed. Rio de Janeiro: Zahar/Garamond, 1999.

GLEZER, R. "Chão de Terra": um estudo sobre São Paulo colonial.Tese (Livre Docência) Departamento de História, FFLCH/USP, 1992.

HOMEM, M. C. N. O palacete paulistano e outras formas urbanas de morar da elite cafeeeira (1867-1918). São Paulo: Martins Fontes, 1996.

LAGO, P. C. do L. Militão Augusto deAzevedo: São Paulo nos anos 1860. Rio de Janeiro: Editora Capivara, 2001.

. Iconografia paulistana do século XIX. Rio de Janeiro: Editora Capivara, 2003.

LEM OS, C. O álbum deAfonso. São Paulo:a reforma de São Paulo. São Paulo:Edições Pinacoteca do Estado, 2001.

LÉRIAS, R. A. O Encilhamento e a cidade de São Paulo, 1890-1891. Dissertação (Mestrado) Departamento de História, FFLCH/USP, 1988. 
MARCÍLIO, M. L. A estrutura da população In:A cidade de São Paulo: povoamento e população 1750-1850. São Paulo: Pioneira, 1974,

MARINS, P.C. G. Sociabilidades paulistanas. In: Através da rótula. Sociedade e arquitetura urbana no Brasil Sécs.XVII-XX. Tese (Doutorado) - Departamento de História, FFLCH/USP, 1999. p. 150 260.

. Mulheres de elite, filhos naturais - São Paulo, séculos XVIII e XIX. In: FUKUI, L. (org.). Segredos de família. São Paulo: Annablume/ Nemge/ USP/ Fapesp, 2002.

MARX, M. Cidade no Brasil, terra de quem? São Paulo: Nobel/Edusp, 1991.

MELLO, Z. M. C. de. Metamorfoses da riqueza. São Paulo, 1845-1895. São Paulo: Hucitec, 1985.

MEMÓRIA URBANA. A Grande São Paulo até 1940. São Paulo: Arquivo do Estado/Emplasa/Imprensa Oficial, 2001.

OLIVEIRA, M. L. F. de. Relações sociais e experiência da urbanização. São Paulo, 1870-1900. Tese (Doutorado) - Departamento de História, FFLCH/USP, 2003.

PIRES,W. Configuração territorial, urbanização e patrimônio:Colônia da Glória (1876-1904). Dissertação (Mestrado) - FAU/USP, 2003.

REIS FILHO, N. G. São Paulo:vila, cidade e metrópole. São Paulo:Via das Artes, 2004.

ROLNIK, R. Mercados: legislação urbana e valorização imobiliária. In: A cidade e a lei. Legislação, política urbana e territórios na cidade de São Paulo. 3a ed. São Paulo: Fapesp/ Nobel, 2003, p. 101-143.

SAINT-HILAIRE,A. Viagem à Província de São Paulo. Belo Horizonte: Itatiaia; São Paulo: Edusp, 1976.

SIMÕESJR,J. G. Anhangabaú. História e urbanismo.Tese (Doutorado) - FAU/USP, 1985.

TOLEDO, B. L. de. 0 Triângulo e a configuração de suas ruas e largos. In: Cadernos de fotografia brasileira. São Paulo: Instituto Moreira Salles, 2004. p. 360-380.

Artigo apresentado em 03/2005. Aprovado em 06/2005. 